\title{
Nanomedicine in pulmonary delivery
}

This article was published in the following Dove Press journal:

International Journal of Nanomedicine

4 December 2009

Number of times this article has been viewed

\section{Heidi M Mansour \\ Yun-Seok Rhee \\ Xiao Wu}

University of Kentucky, College of Pharmacy, Division of Pharmaceutical Sciences-Drug Development Division, Lexington, KY, USA
Correspondence: Heidi M Mansour Assistant Professor of Pharmaceutical Sciences and Pharmaceutical Technology, University of Kentucky, College of Pharmacy, Division of Pharmaceutical Sciences-Drug Development Division, 725 Rose Street, Lexington, KY 40536, USA Tel + I 859257 I57|

Email heidi.mansour@uky.edu
Abstract: The lung is an attractive target for drug delivery due to noninvasive administration via inhalation aerosols, avoidance of first-pass metabolism, direct delivery to the site of action for the treatment of respiratory diseases, and the availability of a huge surface area for local drug action and systemic absorption of drug. Colloidal carriers (ie, nanocarrier systems) in pulmonary drug delivery offer many advantages such as the potential to achieve relatively uniform distribution of drug dose among the alveoli, achievement of improved solubility of the drug from its own aqueous solubility, a sustained drug release which consequently reduces dosing frequency, improves patient compliance, decreases incidence of side effects, and the potential of drug internalization by cells. This review focuses on the current status and explores the potential of colloidal carriers (ie, nanocarrier systems) in pulmonary drug delivery with special attention to their pharmaceutical aspects. Manufacturing processes, in vitro/in vivo evaluation methods, and regulatory/toxicity issues of nanomedicines in pulmonary delivery are also discussed.

Keywords: pulmonary delivery, colloidal carriers, nanocarrier systems, liposome, polymeric nanoparticle, solid lipid nanoparticle, submicron emulsion, dendrimer

\section{Introduction}

Burgeoning interest in colloidal carriers (nanocarrier systems) has led to increasing attention for pulmonary drug delivery. The lung is an attractive target for drug delivery due to noninvasive means to provide not only local lung effects but possibly high systemic bioavailability, avoidance of first-pass metabolism, more rapid onset of therapeutic action, and the availability of a huge surface area. ${ }^{1,2}$ Nanocarrier systems in pulmonary drug delivery offer many advantages. These advantages include the following: 1) the potential to achieve relatively uniform distribution of drug dose among the alveoli; 2) an achievement of enhanced solubility of the drug than its own aqueous solubility; 3 ) the sustained-release of drug which consequently reduces the dosing frequency; 4) suitability for delivery of macromolecules; 5) decreased incidence of side effects; 6) improved patient compliance; and 7) the potential of drug internalization by cells.,

Nanotechnology has been described as the manipulation, precision placement, measurement, modeling or manufacture of matter in the sub-100 nm range, ${ }^{5}$ although, depending on the context, the term sometimes identifies particles in the 1 to $200 \mathrm{~nm}$ range. ${ }^{3,6}$ However, the $100 \mathrm{~nm}$ limit is constraining, as in effect it would disregard many recent achievements and a plethora of basic science (interfacial and colloidal chemistry) literature and pharmaceutical research literature reports. In addition, there are a number of literature reports in both the basic science and pharmaceutical literature 
which scientifically define dimensions of nanoparticles ranging in size from 1 to $1000 \mathrm{~nm} \cdot{ }^{3,7-9}$ In drug delivery systems, submicron size is significant because biodistribution of submicron particles are critical and some safety issues may be occurred when we use microparticles. For instance, after intravenous injection of parenteral formulation, large particles $(>5 \mu \mathrm{m})$ can cause pulmonary embolism, which can induce fatal results, ${ }^{10,11}$ therefore submicron particle size is required for parenteral formulations. Although the upper limit of particle size for ophthalmic application is about $5 \mu \mathrm{m}$, the optimum particle size is less than $1,000 \mathrm{~nm}$ because a scratching feeling can occur when microparticles are applied to the eyes. ${ }^{12}$ Phagocytosis is sensitive to particle size, and it is generally thought that particles of $0.5-3 \mu \mathrm{m}$ in diameter are taken up by macrophages,${ }^{13}$ and particles of less than $0.26 \mu \mathrm{m}$ can escape from phagocytosis by macrophages. ${ }^{1}$ Phagocytosis is also the main mechanism responsible for the rapid clearance of particulate drug delivery systems from the body. Furthermore, cytosolic delivery of drugs can be achieved by endocytosis of submicron drug carriers. Therefore, in this review, the authors consider all particulates for which at least one dimension is $1-1000 \mathrm{~nm}$.

There are numerous applications for nanotechnology, however, especially the treatment, diagnosis, monitoring and control of biological systems have recently been referred to as "nanomedicine" by the National Institutes of Health (Bethesda, MD, USA) ${ }^{14}$ In short, nanomedicine is the application of nanotechnology to medicine, and two main types of nanomedicine products are currently in clinical trials: diagnostic tests and drug delivery devices. ${ }^{15}$ Over the past decades, efforts have been focused on the development of nanomedicines such as nanoparticles, liposomes, nanoemulsions, or dendrimers for the specific delivery of drugs to the target tissues.

The modern inhalation devices can be divided into three different categories, nebulizers, pressurized metered dose inhalers (pMDI), and dry powder inhalers (DPI). ${ }^{1}$ In most cases, nanocarriers can be delivered to the lungs by nebulization of colloidal dispersions or using pMDIs and DPIs in solid form. ${ }^{1,3}$ Due to small size and strong particleparticle interactions of nanocarriers, particle agglomeration and settlement can occur in colloidal dispersions. Moreover, chemical instability of colloidal dispersions is another issue owing to carrier hydrolysis and drug degradation. To improve physical and chemical instability of nanocarrier dispersions, freeze-drying of nanocarriers has been explored as a means to provide a storage form. However, redispersibility and the use of stabilizers for lyophilization are still problematic in nebulization. The use of a nanocarrier itself for delivery to lungs is severely limited because individual nanocarriers do not deposit efficiently in the lungs by diffusion, sedimentation or impaction, which results in the exhalation of a majority of the inhaled dose. ${ }^{3}$ Therefore, micron-sized powder carriers containing nanoparticles or agglomerated nanoparticles were designed to improve the inhalation aerosol delivery of nanoparticles for deep lung delivery by using MDIs and DPIs. ${ }^{1}$ A thorough discussion of incorporating nanoparticles into micron-scale structures or processing methods for agglomerated nanoparticles are beyond the scope of this review, but the topic has been recently reviewed elsewhere. ${ }^{3,4,16}$

This review focuses on the current status and explores the potential of colloidal carriers (nanocarrier systems) in pulmonary drug delivery with special attention to and in depth presentation of their pharmaceutical aspects. Manufacturing processes, in vitro/in vivo evaluation methods, and regulatory/toxicity issues of nanomedicines in pulmonary delivery are also presented and discussed.

\section{Drugs for inhalation}

Various drugs are investigated for local or systemic pulmonary delivery. ${ }^{2}$ These include small molecules, protein/ peptide drug and genes (Table 1). In case of small molecule drugs, many studies were focused on local application for the treatment of chronic respiratory diseases such as asthma and chronic obstructive pulmonary disease (COPD). However, pulmonary protein/peptide delivery offers great potential for both local targeting for the treatment of respiratory diseases and systemic targeting for the treatment of diabetes mellitus or thrombosis. Gene delivery to the lungs are mainly focused on the localized delivery of drugs to the site of disease, the lungs and airways, including lung cancer, genetic disorders affecting the airways (cystic fibrosis, alpha-1-antitrypsin deficiency), obstructive lung diseases (asthma), and vaccination. Since original aerosol technology was developed for small molecule drugs, it is necessary to evolve the reengineering of nanocarrier self-assembly systems for macromolecular pulmonary delivery. ${ }^{17}$ Examples of drugs for pulmonary nanocarrier systems are shown in Figure 1. ${ }^{18-28,29-76}$

\section{Nanocarrier systems for pulmonary drug delivery Polymeric nanoparticulate pulmonary delivery}

Polymeric nanoparticles are widely studied in drug delivery system for parenteral administration; $;^{77,78}$ however 
Table I Examples of drugs for pulmonary delivery using colloidal carrier self-assembly systems

\begin{tabular}{|c|c|c|}
\hline Therapeutic areas and drugs & Drug types $^{a}$ & $\begin{array}{l}\text { Colloidal carrier self-assembly } \\
\text { systems and references }^{b}\end{array}$ \\
\hline \multicolumn{3}{|l|}{ Asthma (anti-inflammatory) } \\
\hline Budesonide & $\mathrm{S}$ & $\mathrm{LP}^{2,3} \mathrm{DN}^{4,5}$ \\
\hline Syk antisense oligodeoxynucleotides & G & $\mathrm{LP}^{6}$ \\
\hline Ketotifen & $S$ & $\mathrm{LP}^{7}$ \\
\hline Ibuprofen & S & $\mathrm{DN}^{8}$ \\
\hline Interleukin-4 antisense oligodeoxynucleotides & G & $\mathrm{PN}^{9}$ \\
\hline Indomethacin, ketoprofen & S & $\mathrm{SLN}^{10}$ \\
\hline Vasoactive intestinal peptide & $P$ & LP, ${ }^{1-13} \mathrm{PN}^{14}$ \\
\hline Dexamethasone palmitate & S & LP15 \\
\hline Fluticasone & $\mathrm{S}$ & $\mathrm{DN}^{5}$ \\
\hline \multicolumn{3}{|l|}{ Pulmonary hypertension } \\
\hline Vasoactive intestinal peptide ${ }^{c}$ & $P$ & LP, ${ }^{1-13} \mathrm{PN}^{14}$ \\
\hline Vascular endothelial growth factor (VEGF) gene & G & $\mathrm{LP}^{16}$ \\
\hline Nuclear factor $\kappa B$ decoy oligodeoxynucleotides & G & NP17 \\
\hline Nifedipine & $\mathrm{S}$ & $\mathrm{DN}^{18}$ \\
\hline \multicolumn{3}{|l|}{ Cystic fibrosis } \\
\hline Amiloride hydrochloride & S & $\mathrm{LP}^{19}$ \\
\hline Secretory leukocyte protease inhibitor & $P$ & $\mathrm{LP}^{20}$ \\
\hline \multicolumn{3}{|l|}{ Infections } \\
\hline Tobramycin & $S$ & $\mathrm{LP}^{21,22} \mathrm{DN}^{23}$ \\
\hline Rifampicin & S & $\mathrm{LP}^{24-27} \mathrm{PN}^{28-31} \mathrm{SLN}^{32}$ \\
\hline Isoniazid, pyrazinamide & S & $\mathrm{PN},{ }^{28,29} \mathrm{LP}_{,}^{27} \mathrm{SLN}^{32}$ \\
\hline Ciprofloxacin & S & $\mathrm{LP}^{33,34}$ \\
\hline Amphotericin B & S & $\mathrm{LP}^{35,36}$ \\
\hline Itraconazole & $\mathrm{S}$ & $\mathrm{DN}^{37-40}$ \\
\hline \multicolumn{3}{|l|}{ Lung cancers } \\
\hline Interleukin-2 & $P$ & $\mathrm{LP}^{41}$ \\
\hline p53 gene & G & $\mathrm{PN}^{42-45}$ \\
\hline 9-nitrocamptothecin & S & $\mathrm{LP}^{46}$ \\
\hline Leuprolide & $P$ & $\mathrm{LP}^{47}$ \\
\hline Doxorubicin & S & $\mathrm{PN}^{48}$ \\
\hline Programmed cell death protein 4 (PDCD4) & $P$ & $\mathrm{PN}^{49,50}$ \\
\hline Antisense oligonucleotide 2'-O-methyl-RNA & G & $\mathrm{PN}^{51}$ \\
\hline Aktl (protein kinase B) siRNA & G & $\mathrm{PN}^{52,53}$ \\
\hline $\begin{array}{l}\text { 6-\{[2-(dimethylamino)ethyl]amino\}-3-hydroxyl-7H-indeno[2,I-c] } \\
\text { quinolin-7-one dihydrochloride }\end{array}$ & S & $\mathrm{PN}^{54}$ \\
\hline \multicolumn{3}{|l|}{ Mutative defects in lung } \\
\hline Chimeric oligonucleotide & G & $\mathrm{PN}^{55}$ \\
\hline \multicolumn{3}{|l|}{ Immune modulators } \\
\hline Cyclosporine A & $P$ & $\mathrm{LP}^{56} \mathrm{DN}^{57,58}$ \\
\hline Tacrolimus & S & LP' \\
\hline \multicolumn{3}{|l|}{ Vaccination } \\
\hline HLA-A*020I-restricted T-cell epitopes from Mycobacterium tuberculosis & G & $\mathrm{PN}^{60}$ \\
\hline VIJns plasmid encoding antigen 85B from M. tuberculosis & G & $\mathrm{SE}^{61}$ \\
\hline \multicolumn{3}{|l|}{ Reactive oxygen species mediated diseases } \\
\hline Superoxide dismutase & $P$ & LP'-64 \\
\hline
\end{tabular}


Table I (Continued)

\begin{tabular}{lll}
\hline Therapeutic areas and drugs & $\begin{array}{c}\text { Drug types }^{\mathrm{a}} \\
\begin{array}{l}\text { Colloidal carrier self-assembly } \\
\text { systems and references }^{b}\end{array}\end{array}$ & $\begin{array}{c}\mathrm{PN}^{65} \\
\text { Parathyroid disease }\end{array}$ \\
$\quad \begin{array}{l}\text { Elcatonin } \\
\text { Diabetes }\end{array}$ & $\mathrm{P}$ & $\mathrm{PN}^{66} \mathrm{LP}^{67,68} \mathrm{SLN}^{69}$ \\
$\quad$ Insulin & & $\mathrm{DD}^{70,71}$ \\
$\begin{array}{l}\text { Thrombosis } \\
\text { Low molecular weight heparin } \\
\text { Urokinase }\end{array}$ & $\mathrm{P}$ & $\mathrm{PN}^{72}$ \\
\hline
\end{tabular}

Notes: aS, small molecules; P, protein/peptide; G, gene; 'DN, drug nanoparticle; PN, polymeric nanoparticle; LP, liposome; SLP, solid lipid nanoparticle; DD, dendrimer; $\mathrm{SE}$, submicron emulsion; 'Can be used for treatment of pulmonary hypertension as well as asthma.

their application to the pulmonary routes are also widely recognized. ${ }^{4}$ The main roles of polymeric nanoparticles in drug delivery system are to carry the drug molecules, to protect drugs from degradation, and to control drug release. ${ }^{78}$ Therapeutically used polymeric nanoparticles are composed of biodegradable or biocompatible materials, such as poly( $\varepsilon$-caprolactone) (PCL), poly(lactic acid) (PLA), poly(lactic-co-glycolic acid) (PLGA), alginic acid, gelatin and chitosan. Various polymers for pulmonary drug delivery using nanocarrier systems are shown in Table 2. The chemical structures of polymers for polymeric nanoparticles used in pulmonary delivery systems are shown Figure 2. ${ }^{26,29,38,39,54-57,59,61,69,70,74,75,79-93}$

Due to their biocompatibility, surface modification capability, and sustained-release properties, polymeric nanoparticles are intensively studied using various important pulmonary drugs. These pulmonary drug include antiasthmatic drugs, ${ }^{22,26}$ antituberculosis drugs, ${ }^{38,39}$ pulmonary hypertension drugs, ${ }^{29}$ and anticancer drugs. ${ }^{54}$ However, to avoid accumulation of polymer carriers following repeated dosing, the biodegradability and toxicity of polymers over the long term should be closely examined in the formulation of polymeric nanoparticles for pulmonary delivery. Additionally, in vitro lung surfactant models and in vivo studies are required to establish the pulmonary acceptability of polymeric nanocarrier systems, as polymers and their degradation products can affect the vital surfactant properties in the alveoli which in turn will affect pulmonary immunity control and adversely affect the work of breathing.

Although cationic lipid-based gene carriers are currently being clinically evaluated further than polymer-based gene carriers, ${ }^{94}$ cationic polymers are one of the popular carriers for gene delivery to the lungs. ${ }^{95,96}$ Although polyethyleneimine (PEI) and polyamino acids, such as poly-L-lysine, have been shown to be effective agents for DNA delivery both in vitro and in vivo, ${ }^{97,98}$ cytotoxicity ${ }^{99}$ and low transfection efficacy problems when delivered via inhalation have to be overcome. ${ }^{100}$ To solve these problems, various modifications of PEI with liposomes/PEGs or conjugations of PEI with ligands such as transferrin have been investigated extensively. ${ }^{101-107}$ Noninvasive pulmonary gene delivery using cationic polymers has been reviewed in detail elsewhere. ${ }^{95}$

\section{Liposomal pulmonary delivery}

Liposomes are one of the most extensively investigated systems for controlled delivery of drug to the lung. ${ }^{108}$ Liposomes seem particularly appropriate for therapeutic agent delivery to lung, since these vesicles can be prepared from compounds endogenous to the lungs, such as the components of lung surfactant, and these properties make liposomes attractive candidates as drug delivery vehicles. ${ }^{37}$ The first pharmaceutical liposomal products in market include the synthetic lung surfactant Alveofact ${ }^{\circledR}$ (Dr Karl Thomae GmbH, Biberach, Germany) for pulmonary instillation for the treatment of respiratory distress syndrome (RDS). ${ }^{109}$ Typically, liposomal formulations have been delivered to the lung in the liquid state, and nebulizers have been used extensively for the aerosol delivery of liposomes in the liquid state. ${ }^{110}$ However, concerns arise from drug stability in the liquid state and leakage when nebulizers are used to deliver a liposomal encapsulated agent. ${ }^{111}$ Recently, liposomal dry powder formulations have been intensively examined in order to successfully circumvent these issues. ${ }^{72,112-114}$ Liposomal dry powder formulations have been shown to be very promising in the delivery of various types of pulmonary drugs and some of these formulations are currently in clinical trials.

Much interest has focused on cationic liposomes for pulmonary gene delivery because cationic liposomes offer the advantage of self-assembly with DNA material through favorable cationic-anionic electrostatic interactions. Additional advantages include evasion from complement 


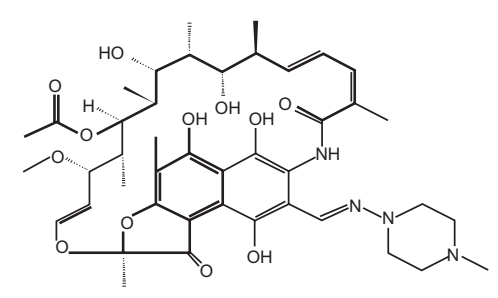

Rifampicin

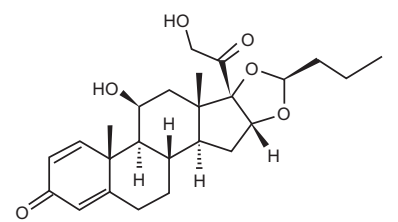

Budesonide

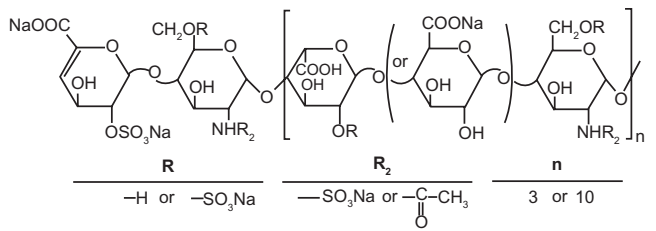

Low molecular weight heparin (Enoxaparin)

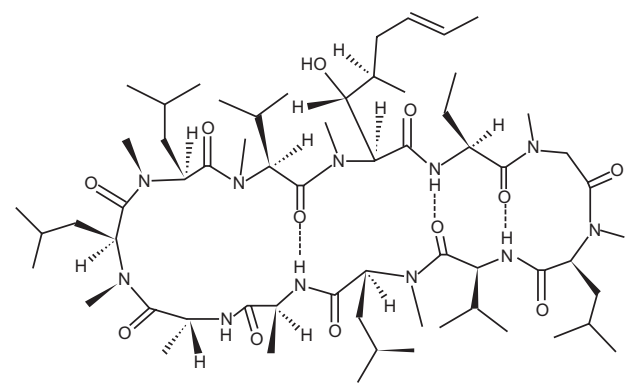

Cyclosporine A

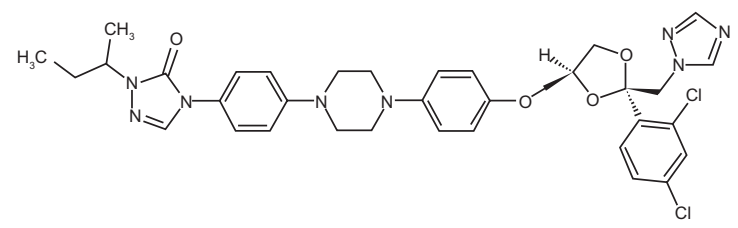

Itraconazole

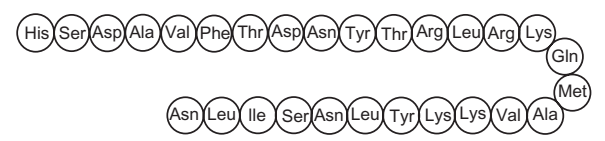

Vasoactive intestinal peptide

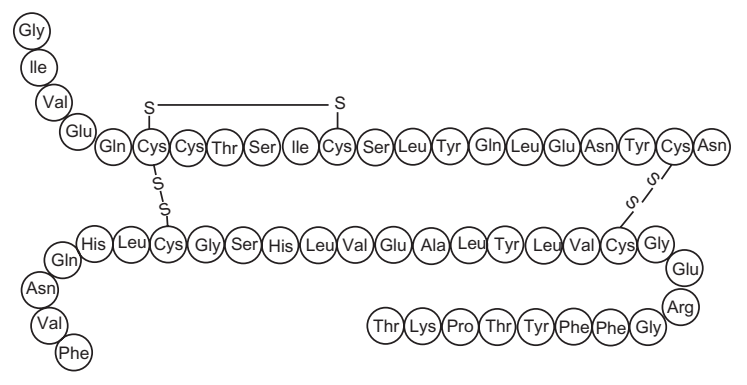

Insulin

Figure I Examples of drugs for pulmonary colloidal carriers (nanocarrier systems).

inactivation after in vivo administration, the low cost and relative ease in producing nucleic acid-liposome complexes in large scale. ${ }^{95}$ After first report of inhalation gene delivery success, ${ }^{115}$ many reports have been published on gene delivery using cationic liposomes by pulmonary administration. ${ }^{104,116-123}$ Many recent reviews ${ }^{95,124,125}$ present gene delivery system using cationic liposomes. Moreover, liposomes conjugated with cell-penetrating peptides are recognized as potential nanocarrier systems for intracellular delivery of macromolecules to the lung. Liposomes modified with cell-penetrating peptides, antennapedia, the HIV-1 transcriptional activator, and octaarginine have been reported to enhance the cellular uptake of liposomes to airway cells. ${ }^{126}$

\section{Solid lipid nanoparticles in pulmonary delivery}

Solid lipid nanoparticles (SLNs) are made from solid lipids (ie, lipids solid at room temperature), surfactant(s) and water. ${ }^{127}$ Since the beginning of 1990s, the SLNs have been focused on an alternative to polymeric nanoparticles. ${ }^{109}$ The advantages of drug release from SLNs in the 
Table 2 Various polymers for colloidal pulmonary drug delivery systems

\begin{tabular}{|c|c|c|}
\hline Polymers & Drugs and references & Size \\
\hline \multicolumn{3}{|l|}{ Alginate } \\
\hline Sodium alginate & Rifampicin, isoniazid, pyrazinamide ${ }^{29}$ & $235.5 \mathrm{~nm}$ \\
\hline \multicolumn{3}{|l|}{ Chitosan } \\
\hline \multirow[t]{2}{*}{ Chitosan } & Plasmid DNA ${ }^{77}$ & $91-164 \mathrm{~nm}$ \\
\hline & Small interfering $\mathrm{RNA}^{78}$ & $40-600 \mathrm{~nm}$ \\
\hline Chitosan/tripolyphosphate & Insulin ${ }^{79}$ & $300-388 \mathrm{~nm}$ \\
\hline Trisaccharide-substituted chitosan & Plasmid DNA ${ }^{80}$ & $77-90$ nm \\
\hline Urocanic acid-modified chitosan & Programmed cell death protein $4^{50}$ & NA \\
\hline \multicolumn{3}{|l|}{ Gelatin } \\
\hline Gelatin type A & Fuoresceinamine ${ }^{81}$ & $277.8 \mathrm{~nm}$ \\
\hline Gelatin type B & Sulforhodamine 101 acid chloride ${ }^{82}$ & $242 \pm 14 \mathrm{~nm}$ \\
\hline PEGylated gelatin & Plasmid DNA ${ }^{83}$ & $100-500 \mathrm{~nm}$ \\
\hline \multicolumn{3}{|l|}{ Polyalkylcyanoacrylate } \\
\hline \multirow[t]{3}{*}{ Polybutylcyanoacrylate } & Insulin 66 & $254.7 \mathrm{~nm}$ \\
\hline & Doxorubicin ${ }^{84}$ & $173 \pm 43 \mathrm{~nm}$ \\
\hline & Ciprofloxacin ${ }^{85}$ & $156-259 \mathrm{~nm}$ \\
\hline \multicolumn{3}{|l|}{ PLGA } \\
\hline PLGA & Rifampicin, isoniazid, pyrazinamide ${ }^{28}$ & $570-680 \mathrm{~nm}$ \\
\hline PEG-PLGA & Nuclear factor $\kappa B$ decoy oligodeoxynucleotide ${ }^{17}$ & $44 \mathrm{~nm}$ \\
\hline Chitosan-modified PLGA & Elcatonin $^{65}$ & $650 \mathrm{~nm}$ \\
\hline Chitosan/PLGA & Antisense oligonucleotide 2'-O-methyl-RNA ${ }^{51}$ & |35-175 nm \\
\hline $\begin{array}{l}\text { Poly[vinyl 3-(diethylamino)propylcarbamate-co-vinyl } \\
\text { acetate-covinyl alcohol]-graft-PLGA }\end{array}$ & 5(6)-carboxyfluorescein ${ }^{86}$ & $195.3 \pm 7.1 \mathrm{~nm}$ \\
\hline \multicolumn{3}{|l|}{ Proticle } \\
\hline Protamine-oligonucleotide & Vasoactive intestinal peptide ${ }^{14}$ & $\mid 77-318 \mathrm{~nm}$ \\
\hline \multicolumn{3}{|l|}{ PEI } \\
\hline \multirow[t]{2}{*}{ PEI } & Chimeric oligonucleotide $^{55}$ & $30-100 \mathrm{~nm}$ \\
\hline & Plasmid DNA ${ }^{87}$ & $50-100 \mathrm{~nm}$ \\
\hline PEl-alt-PEG & Small interfering $\mathrm{RNA}^{53}$ & NA \\
\hline Glucosylated PEI & Programmed cell death protein $4^{49}$ & NA \\
\hline Galactose-PEG-PEI & Plasmid DNA ${ }^{88}$ & $105-210 \mathrm{~nm}$ \\
\hline Cell-penetrating peptides-PEG-PEI & Plasmid DNA ${ }^{89}$ & I I3-296 nm \\
\hline \multicolumn{3}{|l|}{ Poly-L-lysine } \\
\hline PEGylated poly-L-lysine & Plasmid DNA ${ }^{90,91}$ & $211 \pm 29 \mathrm{~nm}$ \\
\hline \multicolumn{3}{|l|}{ Dendrimer } \\
\hline G9 PAMAM & Plasmid DNA ${ }^{92}$ & NA \\
\hline G2/G3 PAMAM & Low molecular weight heparin ${ }^{70}$ & NA \\
\hline Pegylated G3 PAMAM & Low molecular weight heparin ${ }^{71}$ & $17.1 \pm 3.3 \mathrm{~nm}$ \\
\hline
\end{tabular}

Abbreviations: PEG, poly(ethylene glycol); PLGA, poly(lactic-co-glycolic acid); PEI, poly(ethylenimine); PAMAM, polyamidoamine; NA, not available.

lung are control of the release profile, achievement of a prolonged release and having a faster in vivo degradation compared to particles made from PLA or PLGA. In addition, SLNs proved to possess a higher tolerability in the lungs compared to particles made from some polymeric materials. ${ }^{109,128,129}$ Although SLNs for the pulmonary delivery is not fully appreciated, toxicological profile of SLNs, when using physiological lipids, is expected to be better than that of polymer-based systems, because physiological lipids have little or no cytotoxicicity. ${ }^{130,131}$ It is feasible that aqueous suspensions and perhaps dry powder formulations of SLN can be used for pulmonary inhalation 
<smiles>[X]C(C)(OC(C)C(C)=O)C(=O)COC</smiles>

Poly(lactide-co-glycolide)

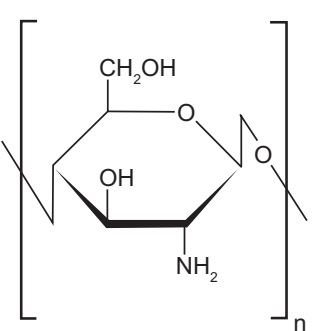

Chitosan<smiles>CCCCOC(=O)C(C)(CC(C)(C)C)C(C)(C)C</smiles>

Polybutylcyanoacrylate<smiles>CC(C)NCCC(C)(C)C</smiles>

Linear polyethyleneimine<smiles>CCNCCN(CCNCCN)CCN(CCNCCN)CCNCCNCCN(CCNCCN)CCNCCNCCN</smiles>

Branched polyethyleneimine

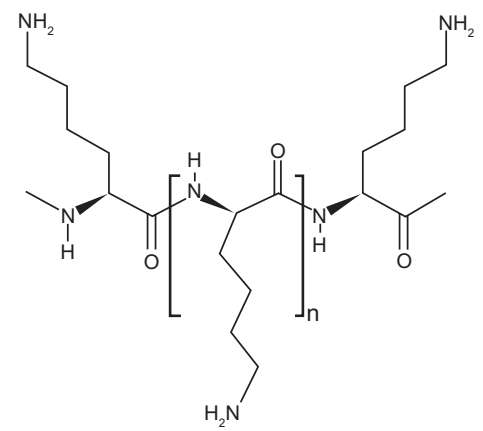

Poly-L-lysine

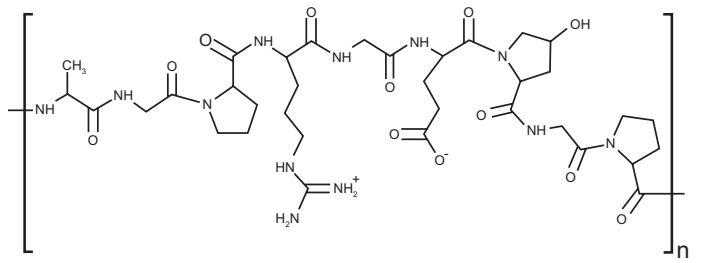

-[Ala-Gly-Pro-Arg-Gly-Glu-4Hyp-Gly-Pro] ${ }_{n-}$

\section{Gelatin}

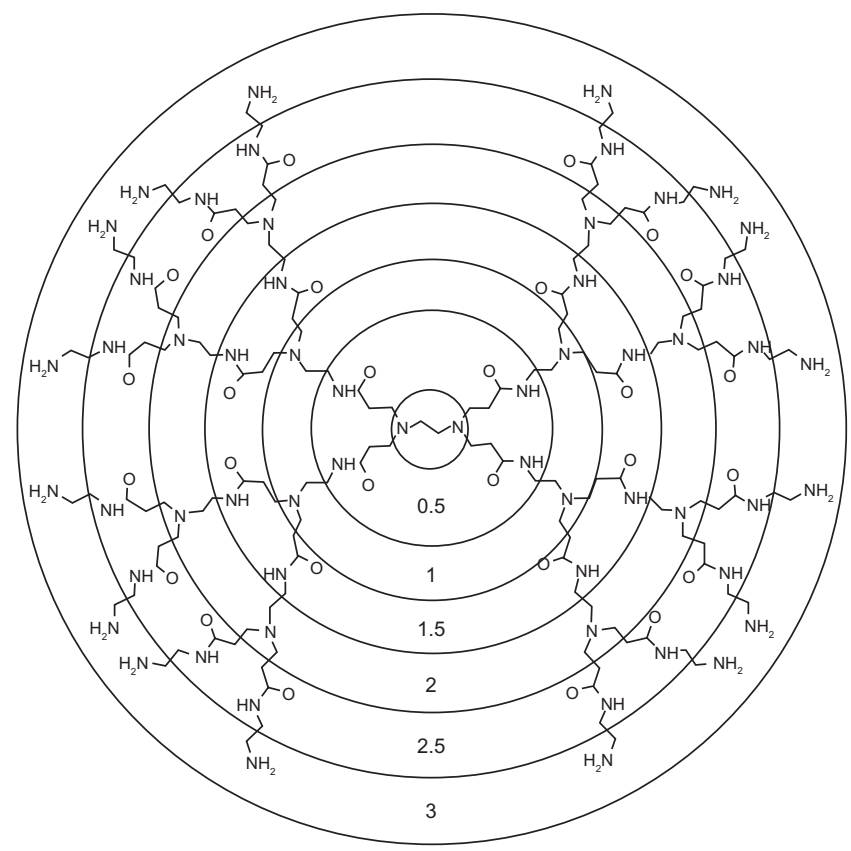

G3 Dendrimer

Figure 2 Chemical structures of polymers for polymeric nanoparticles in pulmonary delivery systems.

aerosol administration of drugs using nebulizers and dry powder inhalers. ${ }^{109}$

Several studies have been published on the pulmonary applications of SLNs as local delivery carriers for small molecules ${ }^{42}$ or as systemic delivery carriers for macromolecules. ${ }^{73,132}$ Pandey and Khuller ${ }^{42}$ studied the chemotherapeutic potential of SLNs incorporating rifampicin, isoniazid and pyrazinamide against experimental tuberculosis, and observed the slow and sustained-release of drugs from the SLNs in vitro and in vivo. Gene delivery 
of SLN-based gene vectors was introduced by Rudolph and colleagues. ${ }^{132}$ They reported that SLN gene vectors mediate gene expression in the mouse lungs upon aerosol application, which was increased by the TAT peptide, and aerosol application of fragile gene delivery systems can be achieved by a mild nebulization technology based on a novel perforated membrane technology. Liu and colleagues ${ }^{73}$ studied novel nebulizer-compatible SLNs containing insulin for pulmonary delivery. They concluded that SLNs could be successfully applied as a pulmonary carrier system for insulin, which might provide novel solutions to the currently unmet medical needs for systemic delivery of proteins.

Deposition and clearance of SLNs were assessed by Videira and colleagues ${ }^{133,134}$ after inhalation of aerosolized insoluble particles using gamma-scintigraphy imaging analysis. It was observed that a few minutes after deposition, inhaled material began to translocate to regional lymph nodes indicating that inhalation can be an effective route to deliver drug-containing lipid partices to the lymphatic systems and lipid particles can be used as potential drug carriers for lung cancer therapy, as well as for vaccine delivery. ${ }^{133,134}$

\section{Submicron emulsions in pulmonary delivery}

Until now, the submicron emulsion system has not yet been fully exploited for pulmonary drug delivery and very little has been published in this area ${ }^{65}$ Cationic submicron emulsion loaded with Mycobacterium tuberculosis Ag85B DNA vaccine was explored vaccine for the purpose of pulmonary mucosal vaccination. ${ }^{65}$ Emulsion systems have been introduced as alternative gene transfer vectors to liposomes. ${ }^{135}$ Other emulsion studies for gene delivery (nonpulmonary route) have shown that binding of the emulsion/DNA complex was stronger than liposomal carriers. ${ }^{136}$ This stable emulsion system delivered genes to endothelial cells in the mouse nasal cavity more efficiently than commercially available liposomes. ${ }^{137}$ Bivas-Benita and colleagues ${ }^{65}$ have reported that cationic submicron emulsions are promising carriers for DNA vaccines to the lung since they are able to transfect pulmonary epithelial cells, which possibly induce cross priming of antigen-presenting cells and directly activate dendritic cells, resulting in stimulation of antigen-specific T-cells. Therefore the nebulization of submicron emulsions will be a new and upcoming research area. However, extensive studies are required for the successful formulation of inhalable submicron emulsions due to possible adverse effects of surfactants and oils on lung alveoli function (adverse interactions with lung surfactant).

\section{Dendrimer-based nanoparticles for lung delivery}

Dendrimers are polymers, which have hyperbranched structures, with layered architectures. ${ }^{138}$ The research in dendrimer-mediated drug delivery has mainly been focused on the delivery of DNA drugs into the cell nucleus for gene or antisense therapy, and many studies have been reported on the possible use of dendrimers as nonviral gene transfer agents. ${ }^{138}$ Several studies have been published regarding pulmonary applications of dendrimers as systemic delivery carriers for macromolecules. ${ }^{74,75,93,139}$

Kukowska-Latallo and colleagues ${ }^{93}$ investigated the ability of polyamido amine (PAMAM) dendritic polymers (dendrimers) to augment plasmid DNA gene transfer in vivo and evaluates the targeting of the lung by alternative routes of administration. They suggested that vascular administration seemed to achieve expression in the lung parenchyma, mainly within the alveoli, while endobronchial administration primarily targeted bronchial epithelium, indicating that each delivery route requires different vectors to achieve optimal transgene expression, that each approach appears to target different cells within the lung.

Rudolph and colleagues ${ }^{139}$ compared the properties of branched polyethylenimine (PEI) $25 \mathrm{kDa}$ and fractured PAMAM dendrimers for topical gene transfer to the airways in vivo. Their results demonstrated that gene transfer mediated by PEI under optimal conditions was two orders of magnitude higher compared to fractured dendrimers. Therefore, branched PEI $25 \mathrm{kDa}$ was superior to fractured dendrimers for gene delivery to the airways.

Bai and colleagues ${ }^{74}$ produced low molecular weight heparin (LMWH)-dendrimer complex through electrostatic interactions using various PAMAM dendrimers, then evaluated both the safety and the efficacy of the drug-dendrimer formulations in preventing deep vein thrombosis in vivo and in situ. They concluded that cationic dendrimers can be used as pulmonary delivery carriers for a relatively large molecular weight anionic drug. These carriers bind anionic drug molecules most likely via electrostatic interactions and increase drug absorption through charge neutralization. In addition, preliminary safety studies using the frog palate model and bronchoalveolar lavage analysis suggest that dendrimers could be viable carriers for pulmonary delivery of LMWH. In another study the same group ${ }^{75}$ also investigated pegylated dendrimers ( $\mathrm{mPEG}-$ dendrimer) in order 
to increase pulmonary absorption and circulation time of the drug. Briefly, half-life and absorption of LMWH administered via the pulmonary route can be increased by encapsulating the drug in dendrimeric micelles, and their study suggests that LMWH loaded in the mPEG-dendrimer could potentially be used as noninvasive delivery system for the treatment of thromboembolic disorder. However, the potential of dendrimers in the pulmonary drug administration route still remains as a challenge that needs further research to achieve lower cytotoxicity and higher biocompatibility.

\section{Manufacture of nanoparticulate inhalation aerosols}

In formulation preparation, several processing technologies have been used to obtain nanoparticles for use as pulmonary inhalation aerosols with desirable attributes, such as narrow particle size distribution, enhanced stability, controlled and targeted release, and improved bioavailability. Jet-milling of the drug under nitrogen gas is the traditional way of creating respirable aerosol particles in the solid-state. ${ }^{140,141}$ The basic procedure of jet-milling is to grind a bulk crystallized particles into small particles by one of the following mechanical forces: pressure, friction, attrition, impact, or shear. However, up until very recently, this technology had a limitation to generate particles in the nanosized range, although a few cases have been reported to produce nanoparticles, such as insulin nanoparticles ${ }^{142}$ and budesonide nanoparticles, ${ }^{143}$ by wet milling process. The recent availability of new nanojet milling instruments which produce nanoparticles by jet milling may increase the routine use of creating nanoparticles by this method.

More sophisticated and advanced manufacturing technologies are utilized to produce respirable aerosol nanoparticles. These respirable particles may be encapsulated in microparticles in the respirable aerodynamice size range of 1-5 microns or the nanoparticles may be designed to aggregate to a favorable aerodynamic size range. These manufacturing nanotechnologies include spray drying (sometimes referred to as advanced spray drying or nanospray drying), spray-freeze drying, supercritical fluid technology, double emulsion/solvent evaporation technology, antisolvent precipitation, particle replication in nonwetting templates (PRINT), and thermal condensation using capillary aerosol generator.

\section{Spray-drying}

Spray-drying is an advanced pharmaceutical manufacturing process used to efficiently produce respirable colloidal particles in the solid-state. ${ }^{144,145}$ In the process, the feed solution is supplied at room temperature and pumped to the nozzle where it is atomized by the nozzle gas. The atomized solution is then dried by preheated drying gas in a special chamber to remove water moisture from the system, thus forming dry particles. These prepared particles are collected with a cyclone separation device. A schematic representation of a spray drying process is shown in Figure 3.

The spray-drying process is suitable for thermolabile materials such as proteins and peptides, because mechanical high energy input is avoided in this process. ${ }^{146-148}$ Moreover, the spray-drying system can be modified to meet specific needs. For example, Maa and colleagues ${ }^{149}$ replaced the bag-filter unit of a spray-drying system with a vacuum to reduce the drying airflow resistance. It allows the protein (recombinant humanized anti-lgE antibody) to be dried at a much lower temperature than usual and the production scale to be increased. ${ }^{146}$ In another study, poly(lactic-co-glycolic acid) particles containing proteins were successfully dried by ultrasonic atomization of feed solution into an atmosphere under reduced pressure. ${ }^{147}$ Solution spray-drying ensures compositional homogeneity of the drug powder, since the drug and the excipients are dissolved prior to the process. More importantly, spray-drying can result in uniform particle morphology. ${ }^{14,149,150}$ In industry, spray-drying is a continuous production method, scalable for commercial production volumes.

Lactose monohydrate is the only US Food and Drug Administration (FDA)-approved sugar carrier for dry powder aerosol formulations and one of a few FDA approved excipients. ${ }^{151}$ For example, lactose with either gelatin or poly(butylcyanoacrylate) nanoparticles were spray dried to produce particles for pulmonary delivery. ${ }^{84}$ Lactose in solid form can be either crystalline as lactose monohydrate or amorphous as lactose. Crystalline lactose can exist in one of two distinct forms: $\alpha$-lactose monohydrate (Figure 4a) and anhydrous $\beta$-lactose (Figure 4b). Amorphous lactose may contain both $\alpha$ - and $\beta$-lactose molecules that are arranged in a more or less random state. $\alpha$-lactose monohydrate and anhydrous $\beta$-lactose are superior in offering better physical stability than amorphous lactose as the later has a tendency to recrystallize spontaneously. ${ }^{152,153} \mathrm{~A}$ disadvantage of lactose monohydrate, a reducing sugar, as a sugar carrier and/or excipient in the solid-state is that it participates in Maillard decomposition reactions with certain small molecular weight pulmonary drugs (eg, budesonide, formoterol), proteins and peptides. ${ }^{154}$ Recently, D-mannitol, a nonreducing sugar alcohol, whose molecular structure is shown in Figure 4c, has 


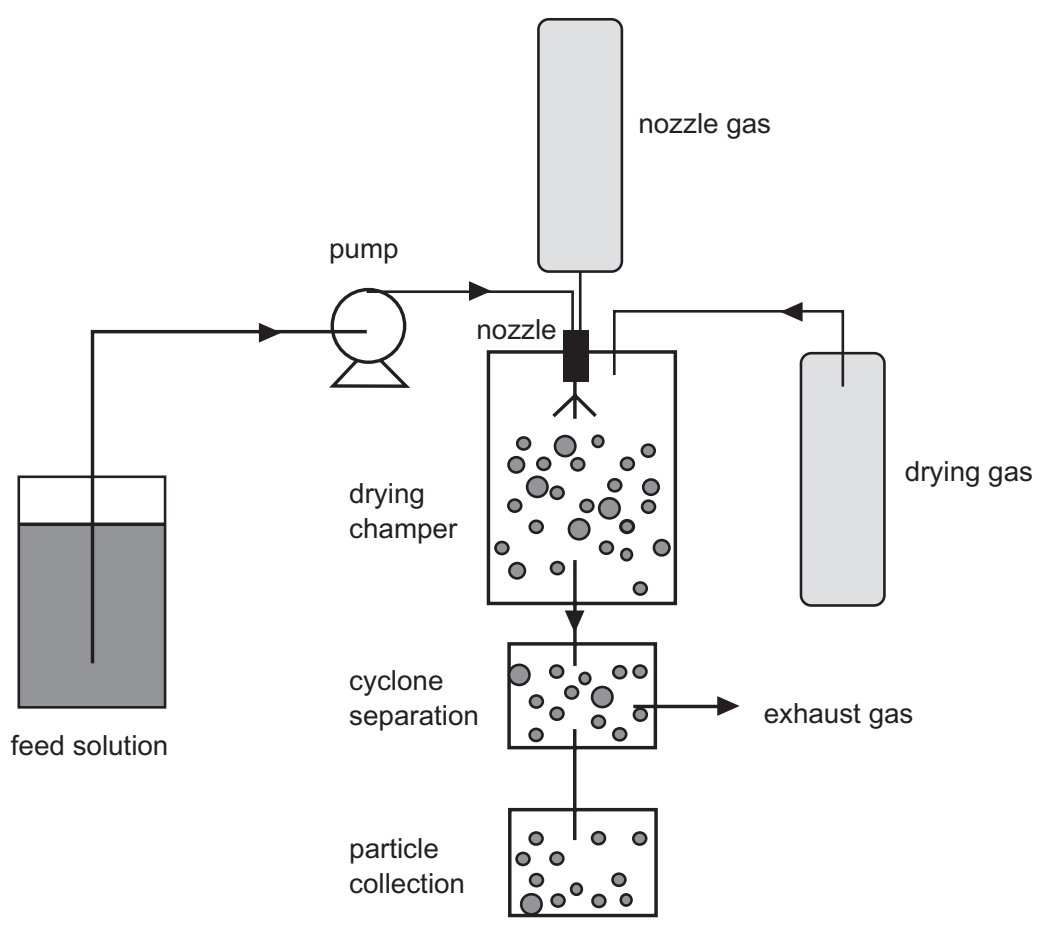

Figure 3 A schematic representation of the spray-drying process.

been used as an alternative sugar carrier of pulmonary drugs in dry powder inhalation aerosols, since it does not participate in the solid-state decomposition Maillard reaction. ${ }^{155}$

\section{Spray-freeze-drying (SFD)}

Spray-freeze-drying (SFD) is an advanced particle engineering method which combines spray-drying and freeze-drying processing steps. This technique involves the atomization of an aqueous drug solution into a spray chamber filled with a cryogenic liquid (liquid nitrogen) or halocarbon refrigerant such as chlorofluorocarbon or fluorocarbon. ${ }^{156}$ The water is removed by sublimation after the liquid droplets solidify. ${ }^{157}$ SFD is capable of producing porous particles with high fine particle fraction (FPF) at subambient temperatures. ${ }^{157}$ They are usually low-density composite amorphous particles with high specific surface area. ${ }^{158}$ Thermolabile protein and peptide substances, such as insulin ${ }^{159}$ and plasmid DNA, ${ }^{160}$ can also be formulated into dry powder inhalation products by SFD.

\section{Supercritical fluid technology (SCF)}

The basic feature of the supercritical fluid process is the controlled crystallization of drugs from dispersion in supercritical fluids, carbon dioxide. This method has demonstrated a wide range of application in producing pulmonary inhalable formulations. ${ }^{23,161,162}$ Supercritical fluid technology can be divided into several classes. The most important two are supercritical antisolvent precipitation (SAS) $)^{163,164}$ and supercritical fluid extraction of emulsions (SFEE). ${ }^{165,166}$ The fundamental mechanism of SAS is based on rapid precipitation when a drug solution is brought into contact with a supercritical $\mathrm{CO}_{2}$. SFEE is based on extraction of the organic phase in oil-in-water or multiple emulsions using supercritical $\mathrm{CO}_{2}{ }^{165,166}$ The schematic representation of SAS and SFEE processes is shown in Figure 5. Because most of the drugs (eg, asthma drugs) are not soluble in $\mathrm{CO}_{2}$, SAS processes provide an easy and excellent way to produce dry powder inhalation formulations. ${ }^{163,164}$ SFEE can provide uniform crystalline drug nanoparticles, composite nanoparticles containing polymeric materials and the drugs, and nanosuspensions. ${ }^{165,166}$ For instance, Chattopadhyay and colleagues ${ }^{23}$ used a continuous SFEE method to produce nanoparticle suspensions containing one of three lipids (tripalmitin, tristearin, or gelucire 50/13), and one of two model drugs (indomethacin or ketoprofen). The first step of this process was to produce nanoemulsions by mixing organic phase containing lipids, a selected drug and chloroform with aqueous phase containing sodium glycocholate, under high pressure homogenization. Then the nanoemulsions were introduced to an extraction chamber countercurrently to a stream of supercritical $\mathrm{CO}_{2}$. The $\mathrm{CO}_{2}$ extracted the organic solvent from the dispersed droplets, 

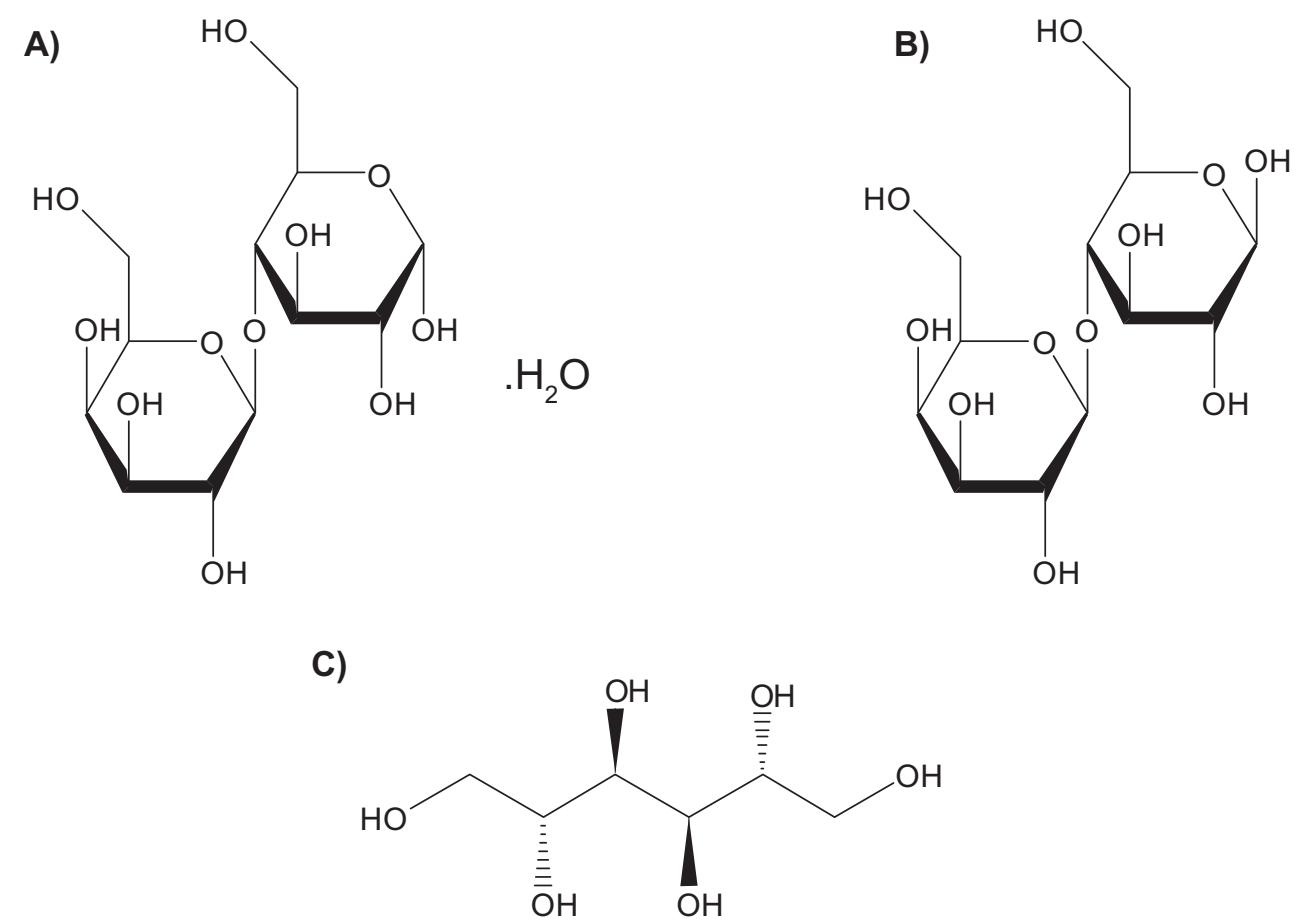

Figure 4 Molecular structures of sugar carriers: A) $\alpha$-lactose monohydrate, B) anhydrous $\beta$-lactose and C) D-mannitol.

forming nanoparticles with a volume mean diameter between 10-30 $\mathrm{nm}$ with a high drug loading efficiency for the gelucire particles $(\sim 80 \%-90 \%)$. In another example, nanoparticles containing cholesterol acetate (CA), griseofulvin (GF), and megestrol acetate (MA) were produced by extraction of the internal phase of oil-in-water emulsions using supercritical carbon dioxide. ${ }^{165}$ This method offered advantages such as the control of particle size, crystallinity, and surface properties. Meanwhile, it shortened the processing time, improved the product purity, and reduced the large waste streams.

\section{Double emulsion/solvent evaporation technique}

Respiratory nanoparticle formation from double emulsion/ solvent evaporation system involves preparation of oil/water (o/w) emulsions with subsequent removal of the oil phase (ie, typically a volatile organic solvent) through evaporation. The emulsions are usually prepared by emulsifying the organic phase containing the drug, polymer and organic solvent in an aqueous solution containing emulsifier. The organic solvent diffuses out of the polymer phase and into the aqueous phase, and is then evaporated, forming drug-loaded polymeric nanoparticles. By this method, biodegradable polymers, including poly(L-lactic acid) (PLA), poly(glycolic) acid (PGA), and poly(lactide-co-glycolide) acid (PLGA), have been intensively investigated as carriers for solid drug nanoparticles. ${ }^{167}$

\section{Antisolvent precipitation}

Crystalline drug particles with narrow size distribution could be prepared by direct controlled crystallization. ${ }^{168}$ This process involves antisolvent precipitation of drug solution in a water-miscible organic solvent, followed by addition of a bridging solvent, which is immiscible or partially miscible with water. Growth-retarding stabilizing additives, such as hydroxylpropylmethylcellulose (HPMC), is usually added in the medium to yield particles with small size. The precipitated drug crystals exhibit a high FPF and low amorphous content. $^{169}$

\section{Particle replication in nonwetting templates (PRINT)}

PRINT is a top-down particle fabrication technique developed by Dr. Joseph DeSimone and his group. This technique is able to generate uniform populations of organic micro- and nanoparticles with complete control of size, shape and surface functionality, and permits the loading of delicate cargos such as small organic therapeutics, peptides, proteins, oligonucleotides, siRNA, contrast agents, radiotracers, and fluorophores. ${ }^{170-172}$ All these features are essential for controlling in vivo transport, biodistribution, 
and drug-release mechanisms of nanoparticles. The principle of PRINT is to utilize a low surface energy fluoropolymeric mold that enables high-resolution imprint lithography, an emerging technique from the microelectronics industry, to fabricate a variety of organic particles. PRINT is therefore an adaptation of lithographic techniques found in the microelectronics industry to fabricate carriers of precise size for use in nanomedicine. Through the use of an appropriately designed master template, PRINT can precisely manipulate particle size ranging from $20 \mathrm{~nm}$ to more than $100 \mu \mathrm{m}$. The shape of particles can be sphere, cylinder, discs, and toroid with defined aspect ratios. PRINT is a promising and novel technology in nanoparticulate design and manufacture for use in pulmonary delivery.

\section{Thermal condensation aerosols}

Thermal condensation is a cutting edge technology which uses capillary aerosol generator (CAG) to produce high concentration condensation submicron to micron sized aerosols from drug solutions. The drug solution is pumped through a heated capillary tube. Precisely controlled heating of the capillary causes the solution to evaporate. Formulation vapor exiting the tip of the capillary tube mixes with the cooler surrounding air, and then becomes supersaturated and initiates nucleation. The condensation of surrounding vapor onto the generated nuclei results in an aerosol. Various drugs, such as perphenazine, ${ }^{173}$ prochlorperazine, ${ }^{174}$ rizatriptan ${ }^{175}$ and benzyl, ${ }^{176}$ have been aerosolized using this technique. Propylene glycol (PG) is a popular solvent chosen to dissolve the drugs. ${ }^{177}$ However, in some cases, rapid heating of thin films of pharmaceutical compounds can also vaporize the molecules, leading to formation of aerosol particles of optimal size for pulmonary drug delivery. ${ }^{178}$ By controlling the film thickness, the purity of aerosols can be enhanced by reducing the amount of aerosol decomposition. ${ }^{179}$

\section{In vitro evaluation methods for pulmonary drug delivery systems In vitro characterization of nanoparticulate aerosol systems}

Nanoparticles for pulmonary drug delivery can be evaluated by comprehensive characterization methods. Table 3 lists several important techniques as well as their functions in the in vitro characterization study of the behavior of nanoparticulate pulmonary inhalation aerosols. ${ }^{180}$

Inertial impaction is the standard method to measure the particle or droplet aerodynamic size from pharmaceutical aerosol delivery systems. ${ }^{181,182}$ It describes the phenomenon of the deposition of aerosol particles on the walls of an airway conduct. The impaction (obstruction) tends to occur where the airway direction changes. The big particles have high momentum (inertia) and are more likely to travel in the initial direction of airflow, while those with low momentum adjust to the new direction of flow and pass around the obstruction. Inertial impaction employs Stokes' law to determine the aerodynamic diameter of particles being evaluated. This has the advantage of incorporating shape and density effects into a single term. ${ }^{141}$

In addition to the conventional commercially available cascade impactors, MSP Corporation (Minneapolis, MN, USA) has recently developed a new commercially available nanomicroorifice uniform deposition impactor

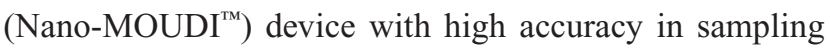
and collecting size-fractionated airborne particle samples and pharmaceutical aerosol particle samples for gravimetric and/or chemical analysis. The Nano-MOUDI ${ }^{\mathrm{TM}}$ differs from conventional cascade impactors by using microorifice nozzles to reduce the jet velocity, pressure drop, particle bounce, and evaporative loss. These impactors also have a uniform deposit feature by rotating the impaction plates with respect to the

Table 3 Methods to characterize the physicochemical and aerodynamic properties of particles (microparticles and nanoparticles) for pulmonary inhalation delivery

\begin{tabular}{ll}
\hline Technology & Function \\
\hline Inertial impaction & Measurement of the aerodynamic size of particles \\
XRPD & Measurement of molecular long-range vs short-range order \\
DSC & Measurement the phase transitions and phase behavior \\
SEM & Visualization of the surface morphology of particles \\
AFM & Surface nanotopographical imaging, surface free energy measurements, and measure of interparticulate forces \\
IGC & Determination of the surface free energy of bulk powders \\
Karl Fisher titration & Analytical quantification of water content in pharmaceutical powders, liquids, and semi-solids \\
\hline
\end{tabular}

Abbreviations: AFM, atomic force microscopy; DSC, differential scanning calorimetry; IGC, indocyanine green; SEM, scanning electron microscopy; XRPD, X-ray particle diffraction. 

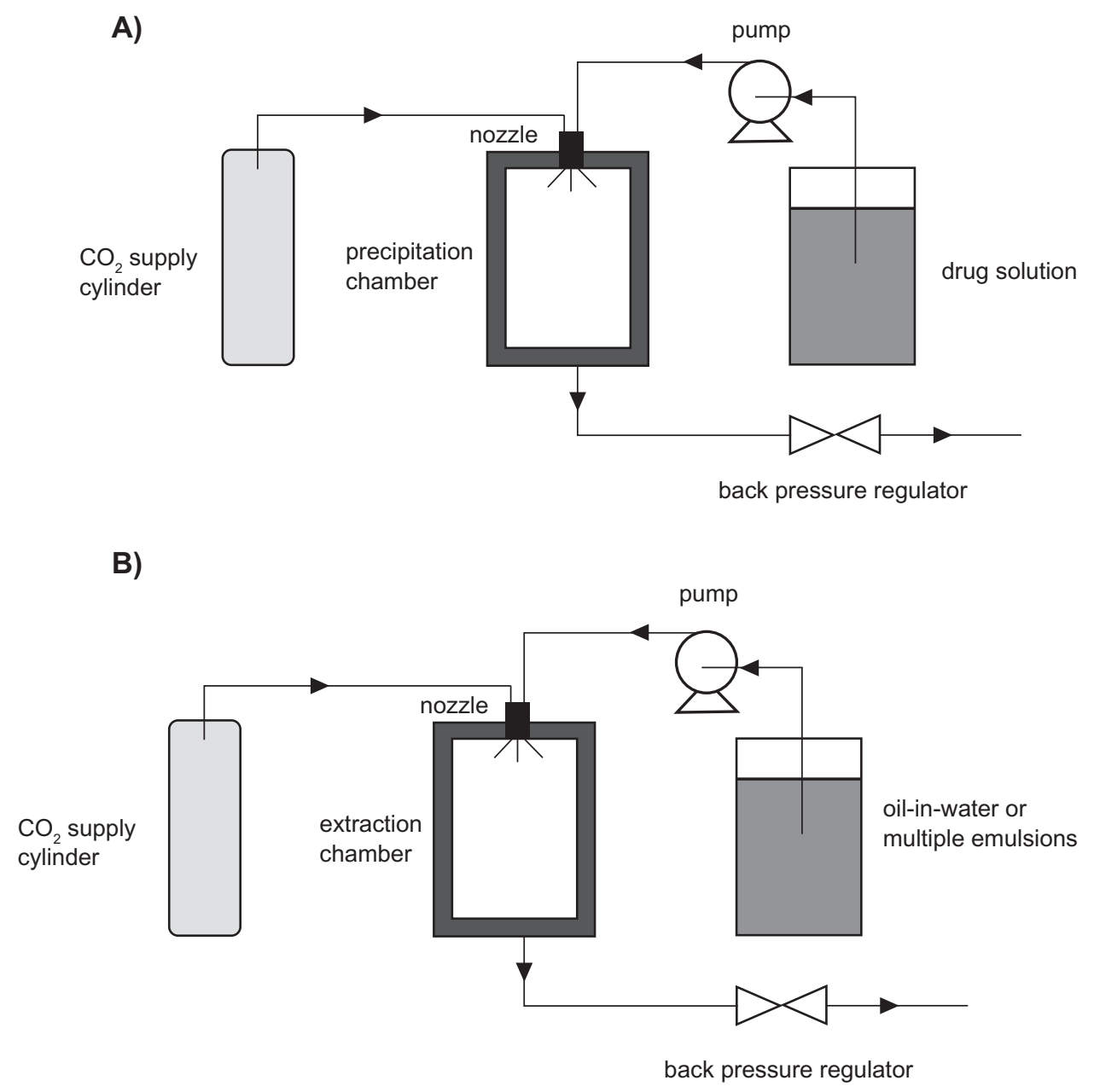

Figure 5 Schematic representations of A) SAS and B) SFEE processes.

nozzles to spread out the particle deposit uniformly on the collection substrates. The uniform deposit prevents heavy particles build-up under each nozzle to reduce particle bounce and blow-off that may otherwise occur. Nano-MOUDI ${ }^{\mathrm{TM}}$ is also superior to conventional cascade impactors in its aerodynamic design features. It is designed to prevent cross-flow interference between adjacent nozzles, which results in sharp cut-size characteristics not available with other cascade impactors. Because of its superior aerodynamic design and outstanding performance characteristics, Nano-MOUDI ${ }^{\mathrm{TM}}$ has an increasing application in environmental air quality and air pollution studies. ${ }^{183-190}$ We believe its application in pharmaceutical nanoaerosol drug delivery characterization and modeling is very promising, as well.

$\mathrm{X}$-ray powder diffraction (XRPD) is one of the most important characterization tools used in solid state chemistry and materials science, since it directly measures the degree of molecular long-range vs short-range order. Molecular long-range order is indicative of crystallinity, while short-range order is indicative of noncrystallinity such as liquid crystallinity and amorphicity. It gives information about the extent and nature of crystallinity and molecular order for solid-state materials, ie, how the atoms pack together in the crystalline state and what the interatomic distance and angle are. ${ }^{191-194}$

Differential scanning calorimetry (DSC) is a powerful and routinely used pharmaceutical thermal analytical method for phase behavior study on polymorphs, hydrates, binding interactions, amorphocity, thermotropic and lyotropic phase transitions of pharmaceutical materials, including nanoparticles. DSC directly measures the gain and loss of enthalpy, that is, order-to-disorder (eg, melting) and disorder-to-order (eg, crystallization) phase transitions. ${ }^{195}$

Scanning electron microscopy (SEM) is used to visualize the surface morphology of particles with a high magnification. The resolution allows identification of specific surface features and asperities that lead to mechanical interlocking (ie, structural cohesion) and that contain high-energy "active" 
sites on the surface which influence surface energetic properties and interparticulate interactions and ultimately influence aerosol dispersion performance. ${ }^{180}$ Surface and interfacial/interparticulate forces are of great importance in the properties of nanoparticles and in the properties of aerosols. Atomic force microscopy (AFM) is used in surface nanotopographical imaging, measurement of surface energy, and measurement of interparticulate forces. This microscopy works in mesoscopic scale resolution $\left(10^{-6}-10^{-9} \mathrm{~m}\right) .{ }^{196}$ Inverse gas chromatography (IGC) measures the surface free energy of bulk powders such as polymers, fibers, and composite materials. ${ }^{197}$

Karl Fischer titration is used to analytically quantify small amounts of water present in the inhalation powder which has important consequences on capillary condensation (ie, capillary force is an important interparticulate force in inhalation aerosol particles), solid-state phase behavior, solid-state properties, and solid-state stability of pharmaceutical particles in the solid-state. ${ }^{198}$

\section{In vitro pulmonary cell culture models}

The lung can be anatomically divided into several parts: the trachea, the main bronchi, the conducting bronchioles, the terminal bronchioles and the alveoli. ${ }^{199,200}$ Drug delivery via inhalation may be absorbed throughout the conducting airway from the trachea down to the terminal bronchioles and ultimately the distal alveoli. ${ }^{201}$ The airway and alveolar epithelium of the lung, which have different cell types, provide barrier capability to drug absorption.

In order to better understand the drug absorption process in different regions (eg, tracheal, bronchial and alveolar) of the respirable barriers, in vitro pulmonary cell culture models have been developed. ${ }^{201-205}$ The cell lines used include A427, A549, HBE14o, and the Calu line (-1, -2 , and -3$).{ }^{205-210}$ These are immortal (continuous) cell lines and hence have different membrane structural features compared with mortal cell lines which influence drug absorption and efflux. For example, A549 cell line represents the alveolar type II pulmonary epithelial cell, and has been reported to be an ideal model to study the metabolic and macromolecule mechanisms of drug delivery at the alveolar pulmonary epithelium because the endocytic ability of the pulmonary epithelium and localization of cytochrome P450 systems is largely a function of type II pneumocytes. ${ }^{209}$ Calu-3 and HBE14o model the upper airways (bronchi) and many studies have been conducted on them. For example, the permeability data of small lipophilic molecule (eg, testosterone) and high molecular weight substance (eg, fluorescein isothiocyanate-transferrin) across Calu-3 cell line has been examined by Foster and colleagues. ${ }^{208}$ The authors demonstrated this cell line is useful for studying the contributions of bronchial epithelial cells to the mechanisms of drug delivery at the respiratory epithelium. Similar conclusions were drawn when the apparent permeability of the glucocorticosteroid budesonide was investigated. ${ }^{206}$

Primary cultured cells have also been used in pulmonary absorption and transport studies. These cell cultures have advantages over continuous cells by exhibiting tight junctions. It is important for cell cultures to form a sufficient and appropriately tight polarized monolayer, so that the transport kinetics of test molecules can be properly assessed. ${ }^{211}$

\section{In vivo evaluation methods for pulmonary drug delivery systems Pharmacokinetic study after nebulization of colloidal dispersion of drugs}

Colloidal drug dispersions have been delivered to male ICR mice via nebulization using a restraint-free small animal inhalation dosing chamber. Then, the mice were sacrificed at pre-determined time points post-dosing. Blood samples were taken by cardiac puncture, and the lungs were harvested for analysis by analytical instrument. From these experiments, lung and serum (blood) pharmacokinetics of colloidal drug dispersions can be determined as reported previously. ${ }^{212-214}$

\section{Biodistribution study using radiolabeled SLNs}

To assess the inhaled radiolabelled SLNs biodistribution, nanoparticles $(200 \mathrm{~nm})$ were radiolabeled with ${ }^{99 \mathrm{~m}} \mathrm{Tc}$ and biodistribution studies were carried out following aerosolisation and administration of a ${ }^{99 m}$ Tc-HMPAO-SLNs suspension to a group of adult male Wistar rats. After administration of radiolabeled SLNs, dynamic image acquisition was performed in a gamma-camera, followed by static image collection. Then radiation counting was performed in organ samples, collected after the animals were sacrificed. From these experiments, biodistribution of SLNs can be traced and evaluated. ${ }^{133,134}$

\section{Fluorescence/bioluminescence imaging systems for pulmonary gene delivery}

Visualization and evaluation of both the pulmonary delivery and the gene expression properties after dry powder inhalation in mice were recently reported by Mizuno and colleagues. ${ }^{215}$ It was shown that the pulmonary delivery and 
the gene expression can be evaluated using fluorescence of indocyanine green (ICG) as a fluorescent label and the detection of luciferase activity, respectively, by using a nondestructive real-time in vivo imaging system. They concluded that the dry powder containing both ICG and pCMV-Luc was useful as a dual imaging system to visualize pulmonary delivery and gene expression in mice.

\section{Regulatory and toxicity issues}

Inhaled microparticles and nanoparticles of different sizes can target into different regions of respiratory tract, including nasopharyngeal, tracheal, bronchial, and alveolar regions, with several mechanisms. Meanwhile, the surface chemistry, charge, shape and aggregation status of nanoparticles also have influences on their disposition efficacy. ${ }^{216}$ For example, inhaled large particles and nanoparticles deposit in the respiratory tract by distinctive mechanisms. Large particles deposit via inertial impaction, gravitation settling and interception mechanisms, while nanoparticles deposits via diffusion due to displacement when they collide with air molecules. The presence of albumin ${ }^{217}$ and phospholipids (eg, lecithin $)^{218}$ in alveolar epithelial lining fluid is important to facilitate epithelial cell uptake of nanoparticles after deposition in the alveolar space. Nanoparticles coated with them may translocate across the alveolo-capilliary barrier, whereas uncoated particles do not. Therefore, when evaluating the efficacy and fate of nanoparticles by inhalation delivery, all the variables should be taken into consideration. $^{1}$

After delivery into the lung, some nanoparticles may be translocated to extrapulmonary sites and reach other target organs by cellular endocytosis, transcytosis, neuronal, ${ }^{219}$ epithelial $^{220}$ and circulatory ${ }^{221}$ translocation and distribution, which makes them desirable for medical therapeutic or diagnostic application. However, these features can also pose potential toxicity. Transcytosis absorbs nanoparticles and translocate them into the interstitial sites, where they gain access to the blood circulation via lymphatics, resulting in distribution throughout the body. Neuronal translocation involves uptake of nanoparticles by sensory nerve endings embedded in airway epithelia, followed by axonal translocation to ganglionic and central nerve systems (CNS) structures. For example, nanoparticles facilitating drug delivery to the CNS in the brain raises the question of fate of nanoparticles after their translocation to the specific cell types or to subcellular structures. This kind of questions includes whether mitochondrial localization induces oxidative stress and how persistent the coating or the core of nanoparticles is, which is essential in nanoparticle toxicology and safety evaluation. .22 $^{22}$

The clearance of nanoparticles in the alveolar region is predominantly mediated by alveolar macrophages, through phagocytosis of deposited nanoparticles. After macrophages recognize the deposited nanoparticles and phagocytize them, macrophages with internalized nanoparticles gradually move toward the mucociliary escalator, and then the clearance process is started. The retention half-time of solid particles in the alveolar region based on this mechanism is very slow, up to 700 days in humans. Moreover, unlike larger particles, results from several studies show the apparent inefficiency of alveolar macrophage phagocytosis of nanosized particles. ${ }^{223-225}$ The ultrafine nanoparticles are not easily phagocytized by macrophages and, consequently, are not readily cleared in the alveolar region. ${ }^{226}$ These nanoparticles are either in epithelium cells or are further translocated to the interstitium, which may cause a long-term accumulation in the lung and subsequent toxicity issues.

According to the FDA guidance for dry powder inhaler (DPI) drug products, $\alpha$-lactose monohydrate is the only approved sugar that can be used as a large carrier particle in dry powder inhalation aerosol products to fluidize and disperse the respiratory drug while itself not being delivered to the lung. Other novel materials, including phospholipids, specifically lecithin and amino acids (lysine, polylysine) have also been developed for use in pulmonary formulations as excipients that are delivered to the lung. A thorough assessment of these alternatives associated with any inhalable substance is required, from a variety of sources: human, animal, and/or in vitro test models. ${ }^{227}$

\section{Conclusions}

Inhalable colloidal carriers (nanocarrier systems) offer numerous advantages. The decrease in particle size leads to an increase in surface area leading to enhanced dissolution rate, as well as relatively uniform distribution of drug dose among the alveoli. In addition, by suspending the drugs in nanoparticles, one can achieve a dose that is higher than that offered by a pure aqueous solution, which is thermodynamically limited by the aqueous solubility of the drug. Nanocarrier systems can provide the advantage of sustained-release in the lung tissue, resulting in reduced dosing frequency and improved patient compliance. Local delivery of inhalable nanocarriers may be a promising alternative to oral or intravenous administration, thus decreasing the incidence of side effects associated with a high drug serum concentration. As with all formulations designed for 
pulmonary drug delivery, the potential long-term risk of excipient toxicity and nanoscale carrier itself are issues that need to be considered in the successful product development of pulmonary drug delivery systems. Nevertheless, their inherently small size and surface modification properties enable further opportunities for innovative controlled drug release and pulmonary cell targeting therapeutic platforms. The integration of nanotechnology and pulmonary delivery has the potential to improve the targeting, release, and therapeutic effects of drugs and needle-free inhalation vaccines with significant potential capability of overcoming the physicochemical and biological hurdles.

\section{Disclosure}

The authors report no conflicts of interest in this work.

\section{References}

1. Yang W, Peters JI, Williams RO 3rd. Inhaled nanoparticles-a current review. Int J Pharm. 2008;356:239-247.

2. Patton JS, Byron PR. Inhaling medicines: delivering drugs to the body through the lungs. Nat Rev Drug Discov. 2007;6:67-74.

3. Sung JC, Pulliam BL, Edwards DA. Nanoparticles for drug delivery to the lungs. Trends Biotechnol. 2007;25:563-570.

4. Bailey MM, Berkland CJ. Nanoparticle formulations in pulmonary drug delivery. Med Res Rev. 2009;29:196-212.

5. Shekunov B. Nanoparticle technology for drug delivery - From nanoparticles to cutting-edge delivery strategies - Part I - 21-22 March 2005, Philadelphia, PA, USA. Idrugs. 2005;8:399-401.

6. Kreuter J. Nanoparticle-based drug delivery systems. J Control Release. 1991;16:169-176.

7. Brigger I, Dubernet C, Couvreur P. Nanoparticles in cancer therapy and diagnosis. Adv Drug Deliv Rev. 2002;54:631-651.

8. Tiwari SB, Amiji MM. A review of nanocarrier-based CNS delivery systems. Curr Drug Deliv. 2006;3:219-232.

9. Kaur IP, Bhandari R, Bhandari S, Kakkar V. Potential of solid lipid nanoparticles in brain targeting. J Control Release. 2008; 127:97-109

10. Driscoll D, Bhargava H, Li L, Zaim R, Babayan V, Bistrian B. Physicochemical stability of total nutrient admixtures. Am J Health Syst Pharm. 1995;52:623-634.

11. Koster VS, Kuks PFM, Lange R, Talsma H. Particle size in parenteral fat emulsions, what are the true limitations? Int J Pharm. 1996;134: 235-238.

12. Zimmer A, Kreuter J. Microspheres and nanoparticles used in ocular delivery systems. Adv Drug Deliv Rev. 1995;16:61-73.

13. Chono S, Tanino T, Seki T, Morimoto K. Influence of particle size on drug delivery to rat alveolar macrophages following pulmonary administration of ciprofloxacin incorporated into liposomes. J Drug Target. 2006;14:557-566.

14. Park JH, Lee S, Kim JH, Park K, Kim K, Kwon IC. Polymeric nanomedicine for cancer therapy. Prog Polym Sci. 2008;33:113-137.

15. Resnik DB, Tinkle SS. Ethical issues in clinical trials involving nanomedicine. Contemp Clin Trials. 2007;28:433-441.

16. Azarmi S, Roa WH, Lobenberg R. Targeted delivery of nanoparticles for the treatment of lung diseases. Adv Drug Deliv Rev. 2008;60:863-875.

17. Cryan SA. Carrier-based strategies for targeting protein and peptide drugs to the lungs. AAPS J. 2005;7:E20-E41.

18. Joshi MR, Misra A. Liposomal budesonide for dry powder inhaler: preparation and stabilization. AAPS Pharm Sci Tech. 2001;2:25.
19. Konduri KS, Nandedkar S, Duzgunes N, et al. Efficacy of liposomal budesonide in experimental asthma. J Allergy Clin Immunol. 2003;111:321-327.

20. Stenton GR, Ulanova M, Dery RE, et al. Inhibition of allergic inflammation in the airways using aerosolized antisense to Syk kinase. J Immunol. 2002;169:1028-1036.

21. Joshi M, Misra A. Disposition kinetics of ketotifen from liposomal dry powder for inhalation in rat lung. Clin Exp Pharmacol Physiol. 2003;30:153-156.

22. Seong JH, Lee KM, Kim ST, Jin SE, Kim CK. Polyethyleniminebased antisense oligodeoxynucleotides of IL-4 suppress the production of IL-4 in a murine model of airway inflammation. $J$ Gene Med. 2006;8:314-323.

23. Chattopadhyay P, Shekunov BY, Yim D, Cipolla D, Boyd B, Farr S. Production of solid lipid nanoparticle suspensions using supercritical fluid extraction of emulsions (SFEE) for pulmonary delivery using the AERx system. Adv Drug Deliv Rev. 2007;59:444-453.

24. Hajos F, Stark B, Hensler S, Prassl R, Mosgoeller W. Inhalable liposomal formulation for vasoactive intestinal peptide. Int J Pharm. 2008;357:286-294.

25. Stark B, Debbage P, Andreae F, Mosgoeller W, Prassl R. Association of vasoactive intestinal peptide with polymer-grafted liposomes: structural aspects for pulmonary delivery. Biochim Biophys Acta. 2007;1768:705-714.

26. Wernig K, Griesbacher M, Andreae F, et al. Depot formulation of vasoactive intestinal peptide by protamine-based biodegradable nanoparticles. J Control Release. 2008;130:192-198.

27. Wijagkanalan W, Kawakami S, Takenaga M, Igarashi R, Yamashita F, Hashida M. Efficient targeting to alveolar macrophages by intratracheal administration of mannosylated liposomes in rats. J Control Release. 2008; $125: 121-130$.

28. Gong F, Tang H, Lin Y, Gu W, Wang W, Kang M. Gene transfer of vascular endothelial growth factor reduces bleomycin-induced pulmonary hypertension in immature rabbits. Pediatr Int. 2005;47: 242-247.

29. Kimura S, Egashira K, Chen L, et al. Nanoparticle-mediated delivery of nuclear factor $\{\mathrm{kappa}\} \mathrm{B}$ decoy into lungs ameliorates monocrotaline-induced pulmonary arterial hypertension. Hypertension. 2009.

30. Chougule MB, Padhi BK, Misra A. Nano-liposomal dry powder inhaler of Amiloride Hydrochloride. J Nanosci Nanotechnol. 2006;6:3001-3009.

31. Gibbons AM, McElvaney NG, Taggart CC, Cryan SA. Delivery of rSLPI in a liposomal carrier for inhalation provides protection against cathepsin L degradation. J Microencapsul. 2008;1-10.

32. Beaulac C, Sachetelli S, Lagace J. Aerosolization of low phase transition temperature liposomal tobramycin as a dry powder in an animal model of chronic pulmonary infection caused by Pseudomonas aeruginosa. J Drug Target. 1999; 7:33-41.

33. Marier JF, Brazier JL, Lavigne J, Ducharme MP. Liposomal tobramycin against pulmonary infections of Pseudomonas aeruginosa: a pharmacokinetic and efficacy study following single and multiple intratracheal administrations in rats. J Antimicrob Chemother. 2003;52: $247-252$.

34. Labana S, Pandey R, Sharma S, Khuller GK. Chemotherapeutic activity against murine tuberculosis of once weekly administered drugs (isoniazid and rifampicin) encapsulated in liposomes. Int J Antimicrob Agents. 2002;20:301-304.

35. Vyas SP, Kannan ME, Jain S, Mishra V, Singh P. Design of liposomal aerosols for improved delivery of rifampicin to alveolar macrophages. Int J Pharm. 2004;269:37-49.

36. Changsan N, Chan HK, Separovic F, Srichana T. Physicochemical characterization and stability of rifampicin liposome dry powder formulations for inhalation. J Pharm Sci. 2009;98:628-639.

37. Justo OR, Moraes AM. Incorporation of antibiotics in liposomes designed for tuberculosis therapy by inhalation. Drug Deliv. 2003;10:201-207. 
38. Pandey R, Sharma A, Zahoor A, Sharma S, Khuller GK, Prasad B. Poly(DL-lactide-co-glycolide) nanoparticle-based inhalable sustained drug delivery system for experimental tuberculosis. J Antimicrob Chemother. 2003;52:981-986.

39. Zahoor A, Sharma S, Khuller GK. Inhalable alginate nanoparticles as antitubercular drug carriers against experimental tuberculosis. Int $J$ Antimicrob Agents. 2005;26:298-303.

40. Esmaeili F, Hosseini-Nasr M, Rad-Malekshahi M, Samadi N, Atyabi F, Dinarvand R. Preparation and antibacterial activity evaluation of rifampicin-loaded poly lactide-co-glycolide nanoparticles Nanomedicine. 2007;3:161-167.

41. Ohashi K, Kabasawa T, Ozeki T, Okada H. One-step preparation of rifampicin/poly(lactic-co-glycolic acid) nanoparticle-containing mannitol microspheres using a four-fluid nozzle spray drier for inhalation therapy of tuberculosis. J Control Release. 2009;135: $19-24$.

42. Pandey R, Khuller GK. Solid lipid particle-based inhalable sustained drug delivery system against experimental tuberculosis. Tuberculosis (Edinb). 2005;85:227-234.

43. Wong JP, Yang H, Blasetti KL, Schnell G, Conley J, Schofield LN. Liposome delivery of ciprofloxacin against intracellular Francisella tularensis infection. J Control Release. 2003;92:265-273.

44. Sweeney LG, Wang Z, Loebenberg R, Wong JP, Lange CF, Finlay WH. Spray-freeze-dried liposomal ciprofloxacin powder for inhaled aerosol drug delivery. Int J Pharm. 2005;305:180-185.

45. Shah SP, Misra A. Development of liposomal amphotericin B dry powder inhaler formulation. Drug Deliv. 2004;11:247-253.

46. Vyas SP, Quraishi S, Gupta S, Jaganathan KS. Aerosolized liposomebased delivery of amphotericin B to alveolar macrophages. Int J Pharm. 2005; 296:12-25.

47. Khanna C, Anderson PM, Hasz DE, Katsanis E, Neville M, Klausner JS. Interleukin-2 liposome inhalation therapy is safe and effective for dogs with spontaneous pulmonary metastases. Cancer. 1997;79:1409-1421.

48. Densmore CL, Kleinerman ES, Gautam A, et al. Growth suppression of established human osteosarcoma lung metastases in mice by aerosol gene therapy with PEI-p53 complexes. Cancer Gene Ther. 2001;8:619-627.

49. Gautam A, Densmore CL, Waldrep JC. Inhibition of experimental lung metastasis by aerosol delivery of PEI-p53 complexes. Mol Ther. 2000;2:318-323.

50. Koshkina NV, Agoulnik IY, Melton SL, Densmore CL, Knight V. Biodistribution and pharmacokinetics of aerosol and intravenously administered DNA-polyethyleneimine complexes: optimization of pulmonary delivery and retention. Mol Ther. 2003;8:249-254.

51. Gautam A, Densmore CL, Melton S, Golunski E, Waldrep JC. Aerosol delivery of PEI-p53 complexes inhibits B16-F10 lung metastases through regulation of angiogenesis. Cancer Gene Ther 2002;9:28-36.

52. Verschraegen CF, Gilbert BE, Loyer E, et al. Clinical evaluation of the delivery and safety of aerosolized liposomal 9-nitro-20(s)-camptothecin in patients with advanced pulmonary malignancies. Clin Cancer Res. 2004;10:2319-2326

53. Shahiwala A, Misra A. A preliminary pharmacokinetic study of liposomal leuprolide dry powder inhaler: a technical note. AAPS Pharm Sci Tech. 2005;6:E482-E486.

54. Azarmi S, Tao X, Chen H, et al. Formulation and cytotoxicity of doxorubicin nanoparticles carried by dry powder aerosol particles. Int J Pharm. 2006;319:155-161.

55. Hwang SK, Jin H, Kwon JT, et al. Aerosol-delivered programmed cell death 4 enhanced apoptosis, controlled cell cycle and suppressed AP-1 activity in the lungs of AP-1 luciferase reporter mice. Gene Ther. 2007; 14:1353-1361.

56. Jin H, Kim TH, Hwang SK, et al. Aerosol delivery of urocanic acidmodified chitosan/programmed cell death 4 complex regulated apoptosis, cell cycle, and angiogenesis in lungs of K-ras null mice. Mol Cancer Ther. 2006;5:1041-1049.
57. Taetz S, Nafee N, Beisner J, et al. The influence of chitosan content in cationic chitosan/PLGA nanoparticles on the delivery efficiency of antisense 2'-O-methyl-RNA directed against telomerase in lung cancer cells. Eur J Pharm Biopharm. 2009;72:358-369.

58. Jere D, Xu CX, Arote R, Yun CH, Cho MH, Cho CS. Poly(betaamino ester) as a carrier for si/shRNA delivery in lung cancer cells. Biomaterials. 2008;29:2535-2547.

59. Xu CX, Jere D, Jin $\mathrm{H}$, et al. Poly(ester amine)-mediated, aerosoldelivered Akt1 small interfering RNA suppresses lung tumorigenesis. Am J Respir Crit Care Med. 2008;178:60-73.

60. Tomoda K, Ohkoshi T, Hirota K, et al. Preparation and properties of inhalable nanocomposite particles for treatment of lung cancer. Colloids Surf B Biointerfaces. 2009;71:177-182.

61. de Semir D, Petriz J, Avinyo A, et al. Non-viral vector-mediated uptake, distribution, and stability of chimeraplasts in human airway epithelial cells. J Gene Med. 2002;4:308-322.

62. Gilbert BE, Knight C, Alvarez FG, et al. Tolerance of volunteers to cyclosporine A-dilauroylphosphatidylcholine liposome aerosol. Am J Respir Crit Care Med. 1997;156:1789-1793.

63. Chougule M, Padhi B, Misra A. Nano-liposomal dry powder inhaler of tacrolimus: preparation, characterization, and pulmonary pharmacokinetics. Int J Nanomedicine. 2007;2:675-688.

64. Bivas-Benita M, van Meijgaarden KE, Franken KL, et al. Pulmonary delivery of chitosan-DNA nanoparticles enhances the immunogenicity of a DNA vaccine encoding HLA-A*0201-restricted T-cell epitopes of Mycobacterium tuberculosis. Vaccine. 2004;22:1609-1615.

65. Bivas-Benita M, Oudshoorn M, Romeijn S, et al. Cationic submicron emulsions for pulmonary DNA immunization. J Control Release. 2004;100:145-155.

66. Kaipel M, Wagner A, Wassermann E, et al. Increased biological half-life of aerosolized liposomal recombinant human $\mathrm{Cu} / \mathrm{Zn}$ superoxide dismutase in pigs. J Aerosol Med Pulm Drug Deliv. 2008;21:281-290.

67. Carpenter M, Epperly MW, Agarwal A, et al. Inhalation delivery of manganese superoxide dismutase-plasmid/liposomes protects the murine lung from irradiation damage. Gene Ther. 2005;12:685-693.

68. Epperly MW, Guo HL, Jefferson M, et al. Cell phenotype specific kinetics of expression of intratracheally injected manganese superoxide dismutase-plasmid/liposomes (MnSOD-PL) during lung radioprotective gene therapy. Gene Ther. 2003;10:163-171.

69. Yamamoto H, Kuno Y, Sugimoto S, Takeuchi H, Kawashima Y. Surfacemodified PLGA nanosphere with chitosan improved pulmonary delivery of calcitonin by mucoadhesion and opening of the intercellular tight junctions. J Control Release. 2005;102:373-381.

70. Zhang Q, Shen Z, Nagai T. Prolonged hypoglycemic effect of insulinloaded polybutylcyanoacrylate nanoparticles after pulmonary administration to normal rats. Int J Pharm. 2001;218:75-80.

71. Huang YY, Wang CH. Pulmonary delivery of insulin by liposomal carriers. J Control Release. 2006;113:9-14.

72. Bi R, Shao W, Wang Q, Zhang N. Spray-freeze-dried dry powder inhalation of insulin-loaded liposomes for enhanced pulmonary delivery. J Drug Target. 2008;16:639-648.

73. Liu J, Gong T, Fu H, et al. Solid lipid nanoparticles for pulmonary delivery of insulin. Int J Pharm. 2008;356:333-344.

74. Bai S, Thomas C, Ahsan F. Dendrimers as a carrier for pulmonary delivery of enoxaparin, a low-molecular weight heparin. J Pharm Sci. 2007;96:2090-2106

75. Bai S, Ahsan F. Synthesis and evaluation of pegylated dendrimeric nanocarrier for pulmonary delivery of low molecular weight heparin. Pharm Res. 2009;26:539-548.

76. Piras AM, Chiellini F, Fiumi C, et al. A new biocompatible nanoparticle delivery system for the release of fibrinolytic drugs. Int J Pharm. 2008;357:260-271.

77. Plumley C, Gorman EM, El-Gendy N, Bybee CR, Munson EJ, Berkland C. Nifedipine nanoparticle agglomeration as a dry powder aerosol formulation strategy. Int J Pharm. 2009;369:136-143.

78. Almeida AJ, Souto E. Solid lipid nanoparticles as a drug delivery system for peptides and proteins. Adv Drug Deliv Rev. 2007;59:478-490. 
79. Koping-Hoggard M, Varum KM, Issa M, et al. Improved chitosanmediated gene delivery based on easily dissociated chitosan polyplexes of highly defined chitosan oligomers. Gene Ther. 2004;11: 1441-1452.

80. Howard KA, Rahbek UL, Liu X, et al. RNA interference in vitro and in vivo using a novel chitosan/siRNA nanoparticle system. Mol Ther. 2006; $14: 476-484$.

81. Grenha A, Seijo B, Remunan-Lopez C. Microencapsulated chitosan nanoparticles for lung protein delivery. Eur J Pharm Sci. 2005;25: 427-437.

82. Issa MM, Koping-Hoggard M, Tommeraas K, et al. Targeted gene delivery with trisaccharide-substituted chitosan oligomers in vitro and after lung administration in vivo. J Control Release. 2006;115: 103-112.

83. Brzoska M, Langer K, Coester C, Loitsch S, Wagner TO, Mallinckrodt $\mathrm{C}$. Incorporation of biodegradable nanoparticles into human airway epithelium cells-in vitro study of the suitability as a vehicle for drug or gene delivery in pulmonary diseases. Biochem Biophys Res Commun. 2004;318:562-570.

84. Sham JO, Zhang Y, Finlay WH, Roa WH, Lobenberg R. Formulation and characterization of spray-dried powders containing nanoparticles for aerosol delivery to the lung. Int J Pharm. 2004;269:457-467.

85. Kaul G, Amiji M. Tumor-targeted gene delivery using poly(ethylene glycol)-modified gelatin nanoparticles: in vitro and in vivo studies. Pharm Res. 2005;22:951-961.

86. Ely L, Roa W, Finlay WH, Lobenberg R. Effervescent dry powder for respiratory drug delivery. Eur J Pharm Biopharm. 2007;65:346-353.

87. Beck-Broichsitter M, Gauss J, Packhaeuser CB, et al. Pulmonary drug delivery with aerosolizable nanoparticles in an ex vivo lung model. Int J Pharm. 2009;367:169-178.

88. Lynch J, Behan N, Birkinshaw C. Factors controlling particle size during nebulization of DNA-polycation complexes. J Aerosol Med. 2007;20:257-268.

89. Chen J, Gao X, Hu K, et al. Galactose-poly(ethylene glycol)-polyethylenimine for improved lung gene transfer. Biochem Biophys Res Commun. 2008;375:378-383.

90. Nguyen J, Xie X, Neu M, et al. Effects of cell-penetrating peptides and pegylation on transfection efficiency of polyethylenimine in mouse lungs. J Gene Med. 2008;10:1236-1246.

91. Ziady AG, Gedeon CR, Muhammad O, et al. Minimal toxicity of stabilized compacted DNA nanoparticles in the murine lung. $\mathrm{Mol}$ Ther. 2003;8:948-956.

92. Ziady AG, Gedeon CR, Miller T, et al. Transfection of airway epithelium by stable PEGylated poly-L-lysine DNA nanoparticles in vivo. Mol Ther. 2003;8:936-947.

93. Kukowska-Latallo JF, Raczka E, Quintana A, Chen C, Rymaszewski M, Baker JR Jr. Intravascular and endobronchial DNA delivery to murine lung tissue using a novel, nonviral vector. Hum Gene Ther. 2000;11:1385-1395

94. de Fougerolles AR. Delivery vehicles for small interfering RNA in vivo. Hum Gene Ther. 2008;19:125-132.

95. Densmore CL. Advances in noninvasive pulmonary gene therapy. Curr Drug Deliv. 2006;3:55-63.

96. De Smedt SC, Demeester J, Hennink WE. Cationic polymer based gene delivery systems. Pharm Res. 2000;17:113-126.

97. Wightman L, Kircheis R, Rossler V, et al. Different behavior of branched and linear polyethylenimine for gene delivery in vitro and in vivo. $J$ Gene Med. 2001;3:362-372.

98. Kichler A, Leborgne C, Coeytaux E, Danos O. Polyethyleniminemediated gene delivery: a mechanistic study. J Gene Med. 2001;3: 135-144.

99. Chollet P, Favrot MC, Hurbin A, Coll JL. Side-effects of a systemic injection of linear polyethylenimine-DNA complexes. J Gene Med. 2002;4:84-91.

100. Tang MX, Szoka FC. The influence of polymer structure on the interactions of cationic polymers with DNA and morphology of the resulting complexes. Gene Ther. 1997;4:823-832.
101. Ogris M, Wagner E. Tumor-targeted gene transfer with DNA polyplexes. Somat Cell Mol Genet. 2002;27:85-95.

102. Rudolph C, Schillinger U, Plank C, et al. Nonviral gene delivery to the lung with copolymer-protected and transferrin-modified polyethylenimine. Biochim Biophys Acta. 2002;1573:75-83.

103. Li SD, Huang L. Surface-modified LPD nanoparticles for tumor targeting. Ann NY Acad Sci. 2006;1082:1-8.

104. Eliyahu H, Joseph A, Schillemans JP, Azzam T, Domb AJ, Barenholz Y. Characterization and in vivo performance of dextranspermine polyplexes and DOTAP/cholesterol lipoplexes administered locally and systemically. Biomaterials. 2007;28:2339-2349.

105. Chono S, Li SD, Conwell CC, Huang L. An efficient and low immunostimulatory nanoparticle formulation for systemic siRNA delivery to the tumor. J Control Release. 2008;131:64-69.

106. Park MR, Kim HW, Hwang CS, et al. Highly efficient gene transfer with degradable poly(ester amine) based on poly(ethylene glycol) diacrylate and polyethylenimine in vitro and in vivo. J Gene Med. 2008;10:198-207.

107. Ko YT, Kale A, Hartner WC, Papahadjopoulos-Sternberg B, Torchilin VP. Self-assembling micelle-like nanoparticles based on phospholipid-polyethyleneimine conjugates for systemic gene delivery. J Control Release. 2009;133:132-138.

108. Zeng XM, Martin GP, Marriott C. The controlled delivery of drugs to the lung. Int J Pharm. 1995;124:149-164.

109. Muller RH, Mader K, Gohla S. Solid lipid nanoparticles (SLN) for controlled drug delivery - a review of the state of the art. Eur J Pharm Biopharm. 2000;50:161-177.

110. Schreier H, Gonzalez-Rothi RJ, Stecenko AA. Pulmonary delivery of liposomes. J Control Release. 1993;24:209-223.

111. Taylor KMG, Taylor G, Kellaway IW, Stevens J. The stability of liposomes to nebulisation. Int J Pharm. 1990;58:57-61.

112. Joshi M, Misra AN. Pulmonary disposition of budesonide from liposomal dry powder inhaler. Methods Find Exp Clin Pharmacol. 2001;23:531-536.

113. Shah SP, Misra A. Liposomal amphotericin B dry powder inhaler: effect of fines on in vitro performance. Pharmazie. 2004;59: $812-813$.

114. White S, Bennett DB, Cheu S, et al. EXUBERA: pharmaceutical development of a novel product for pulmonary delivery of insulin. Diabetes Technol Ther. 2005;7:896-906.

115. Stribling R, Brunette E, Liggitt D, Gaensler K, Debs R. Aerosol gene delivery in vivo. Proc Natl Acad Sci U S A. 1992;89: 11277-11281.

116. Alton EW, Middleton PG, Caplen NJ, et al. Non-invasive liposomemediated gene delivery can correct the ion transport defect in cystic fibrosis mutant mice. Nat Genet. 1993;5:135-142.

117. Chadwick SL, Kingston HD, Stern M, et al. Safety of a single aerosol administration of escalating doses of the cationic lipid GL-67/DOPE/ DMPE-PEG5000 formulation to the lungs of normal volunteers. Gene Ther. 1997;4:937-942.

118. Oudrhiri N, Vigneron JP, Peuchmaur M, Leclerc T, Lehn JM, Lehn P. Gene transfer by guanidinium-cholesterol cationic lipids into airway epithelial cells in vitro and in vivo. Proc Natl Acad Sci US A. 1997;94:1651-1656.

119. Pillai R, Petrak K, Blezinger P, et al. Ultrasonic nebulization of cationic lipid-based gene delivery systems for airway administration. Pharm Res. 1998;15:1743-1747.

120. Densmore CL, Giddings TH, Waldrep JC, Kinsey BM, Knight V. Gene transfer by guanidinium-cholesterol: dioleoylphosphatidylethanolamine liposome-DNA complexes in aerosol. J Gene Med. 1999;1:251-264.

121. Gautam A, Densmore CL, Waldrep JC. Pulmonary cytokine responses associated with PEI-DNA aerosol gene therapy. Gene Ther. 2001;8:254-257.

122. Pitard B, Oudrhiri N, Lambert O, et al. Sterically stabilized BGTCbased lipoplexes: structural features and gene transfection into the mouse airways in vivo. J Gene Med. 2001;3:478-487. 
123. Deshpande DS, Blanchard JD, Schuster J, et al. Gamma scintigraphic evaluation of a miniaturized AERx pulmonary delivery system for aerosol delivery to anesthetized animals using a positive pressure ventilation system. J Aerosol Med. 2005;18:34-44.

124. Templeton NS. Nonviral delivery for genomic therapy of cancer. World J Surg. 2009;33:685-697.

125. Morille M, Passirani C, Vonarbourg A, Clavreul A, Benoit JP. Progress in developing cationic vectors for non-viral systemic gene therapy against cancer. Biomaterials. 2008;29:3477-3496.

126. Cryan SA, Devocelle M, Moran PJ, Hickey AJ, Kelly JG. Increased intracellular targeting to airway cells using octaarginine-coated liposomes: In vitro assessment of their suitability for inhalation. $\mathrm{Mol}$ Pharm. 2006;3:104-112.

127. Mehnert W, Mader K. Solid lipid nanoparticles: production, characterization and applications. Adv Drug Deliv Rev. 2001;47: 165-196.

128. Schwarz C, Mehnert W, Lucks JS, M?ler RH. Solid lipid nanoparticles (SLN) for controlled drug delivery. I. Production, characterization and sterilization. J Control Release. 1994;30:83-96.

129. Westesen K. Novel lipid-based colloidal dispersions as potential drug administration systems - expectations and reality. Colloid Polym Sci. 2000;278:608-618

130. Muller RH, Ruhl D, Runge S, Schulze-Forster K, Mehnert W. Cytotoxicity of solid lipid nanoparticles as a function of the lipid matrix and the surfactant. Pharm Res. 1997;14:458-462.

131. Heydenreich AV, Westmeier R, Pedersen N, Poulsen HS, Kristensen HG Preparation and purification of cationic solid lipid nanospheres-effects on particle size, physical stability and cell toxicity. Int J Pharm. 2003;254:83-87.

132. Rudolph C, Schillinger U, Ortiz A, et al. Application of novel solid lipid nanoparticle (SLN)-gene vector formulations based on a dimeric HIV-1 TAT-peptide in vitro and in vivo. Pharm Res. 2004;21: 1662-1669

133. Videira MA, Gano L, Santos C, Neves M, Almeida AJ. Lymphatic uptake of lipid nanoparticles following endotracheal administration. J Microencapsul. 2006;23:855-862.

134. Videira MA, Botelho MF, Santos AC, Gouveia LF, de Lima JJ, Almeida AJ. Lymphatic uptake of pulmonary delivered radiolabelled solid lipid nanoparticles. J Drug Target. 2002;10:607-613.

135. Liu F, Yang J, Huang L, Liu D. Effect of non-ionic surfactants on the formation of DNA/emulsion complexes and emulsion-mediated gene transfer. Pharm Res. 1996;13:1642-1646.

136. Yi SW, Yune TY, Kim TW, et al. A cationic lipid emulsion/DNA complex as a physically stable and serum-resistant gene delivery system. Pharm Res. 2000;17:314-320.

137. Kim TW, Chung H, Kwon IC, Sung HC, Jeong SY. In vivo gene transfer to the mouse nasal cavity mucosa using a stable cationic lipid emulsion. Mol Cells. 2000;10:142-147.

138. Boas U, Heegaard PM. Dendrimers in drug research. Chem Soc Rev. 2004;33:43-63.

139. Rudolph C, Lausier J, Naundorf S, Muller RH, Rosenecker J. In vivo gene delivery to the lung using polyethylenimine and fractured polyamidoamine dendrimers. J Gene Med. 2000;2:269-278.

140. Hickey AJ. Lung deposition and clearance of pharmaceutical aerosols: what can be learned from inhalation toxicology and industrial hygiene? Aerosol Sci Technol. 1993;18:290-304.

141. Hickey AJ, Mansour HM. Delivery of drugs by the pulmonary route. In: Florence AT, Siepmann J, editors. Modern Pharmaceutics. New York, NY: Taylor and Francis, Inc.; 2008. p. 191-219.

142. Merisko-Liversidge E, McGurk SL, Liversidge GG. Insulin nanoparticles: a novel formulation approach for poorly water soluble $\mathrm{Zn}$ insulin. Pharm Res. 2004;21:1545-1553.

143. Rabinow BE. Nanosuspensions in drug delivery. Nat Rev Drug Discov. 2004;3:785-796.

144. Mosén K, Báckstrom K, Thalberg K. Particle formation and capture during spray drying of inhalable particles. Pharm Dev Technol. 2004;9:409-418.
145. Duddu SP, Sisk SA, Walter YH, et al. Improved lung delivery from a passive dry powder inhaler using an Engineered PulmoSphere powder. Pharm Res. 2002;19:689-695.

146. Maa YF, Nguyen PA, Sit K, Hsu CC. Spray-drying performance of a bench-top spray dryer for protein aerosol powder preparation. Biotechnol Bioeng. 1998;60:301-309.

147. Freitas S, Merkle HP, Gander B. Ultrasonic atomisation into reduced pressure atmosphere - envisaging aseptic spray-drying for microencapsulation. J Control Release. 2004;95:185-195.

148. Stahl K, Claesson M, Lilliehorn P, Linden H, Backstrom K. The effect of process variables on the degradation and physical properties of spray dried insulin intended for inhalation. Int J Pharm. 2002;233:227-237.

149. Gilani K, Najafabadi AR, Barghi M, Rafiee-Tehrani M. The effect of water to ethanol feed ratio on physical properties and aerosolization behavior of spray dried cromolyn sodium particles. J Pharm Sci. 2005;94:1048-1059.

150. Vidgren MT, Vidgren PA, Paronen TP. Comparison of physical and inhalation properties of spray-dried and mechanically micronized disodium cromoglycate. Int J Pharm. 1987;35:139-144.

151. US Food and Drug Administration. Guidance for industry: metered dose inhaler (MDI) and dry powder inhaler (DPI) drug products chemistry, manufacturing, and controls documentation. Rockville, IN: US Department of Health and Human Services; 1998.

152. Kawashima Y, Serigano T, Hino T, Yamamoto H, Takeuchi H. Effect of surface morphology of carrier lactose on dry powder inhalation property of pranlukast hydrate. Int J Pharm. 1998;172:179-188.

153. Vanderbist F, Wery B, Pavon IM, Moes AJ. Optimization of a dry powder inhaler formulation of nacystelyn, a new mucoactive agent. J Pharm Pharmacol. 1999;51:1229-1234.

154. Steckel H, Bolzen N. Alternative sugars as potential carriers for dry powder inhalations. Int J Pharm. 2004;270:297-306.

155. Harjunen P, Lankinen T, Salonen H, Lehto VP, Jarvinen K. Effects of carriers and storage of formulation on the lung deposition of a hydrophobic and hydrophilic drug from a DPI. Int J Pharm. 2003;263:151-163.

156. Rogers T, Johnston K, Williams R. Solution-based particle formation of pharmaceutical powders by supercritical or compressed Fluid $\mathrm{CO}_{2}$ and cryogenic spray-freezing technologies. Drug Dev Ind Pharm. 2001;27:1003-1016.

157. Maa YF, Prestrelski SJ. Biopharmaceutical powders: particle formation and formulation considerations. Curr Pharm Biotechnol. 2000;1:283-302.

158. Maa YF, Nguyen PA, Sweeney T, Shire SJ, Hsu CC. Protein inhalation powders: spray drying vs spray freeze drying. Pharm Res. 1999;16:249-254.

159. Yu Z, Garcia AS, Johnston KP, Williams RO, 3rd. Spray freezing into liquid nitrogen for highly stable protein nanostructured microparticles. Eur J Pharm Biopharm. 2004;58:529-537.

160. Kuo JH, Hwang R. Preparation of DNA dry powder for non-viral gene delivery by spray-freeze drying: effect of protective agents (polyethyleneimine and sugars) on the stability of DNA. J Pharm Pharmacol. 2004;56:27-33.

161. Tom JW, Debenedetti PG. Particle formation with supercritical fluids-a review. J Aerosol Sci. 1991;22:555-584.

162. Rehman M, Shekunov BY, York P, et al. Optimisation of powders for pulmonary delivery using supercritical fluid technology. Eur J Pharm Sci. 2004;22:1-17.

163. Steckel H, Thies J, Muller BW. Micronizing of steroids for pulmonary delivery by supercritical carbon dioxide. Int J Pharm. 1997;152:99-110.

164. Steckel H, Muller BW. Metered-dose inhaler formulation of fluticasone-17-propionate micronized with supercritical carbon dioxide using the alternative propellant HFA-227. Int J Pharm. 1998;173:25-33.

165. Shekunov BY, Chattopadhyay P, Seitzinger J, Huff R. Nanoparticles of poorly water-soluble drugs prepared by supercritical fluid extraction of emulsions. Pharm Res. 2006;23:196-204. 
166. Chattopadhyay P, Huff R, Shekunov BY. Drug encapsulation using supercritical fluid extraction of emulsions. J Pharm Sci. 2006:95:667-679.

167. E1-Baseir MM, Phipps MA, Kellaway IW. Preparation and subsequent degradation of poly(l-lactic acid) microspheres suitable for aerosolisation: a physico-chemical study. Int J Pharm. 1997;151: $145-153$.

168. Rasenack N, Steckel H, Muller BW. Micronization of antiinflammatory drugs for pulmonary delivery by a controlled crystallization process. J Pharm Sci. 2003;92:35-44.

169. Chow AHL, Tong HHY, Chattopadhyay P, Shekunov BY. Particle engineering for pulmonary drug delivery. Pharm Res. 2007:24:411-437.

170. Gratton SEA, Pohlhaus PD, Lee J, Guo J, Cho MJ, DeSimone JM. Nanofabricated particles for engineered drug therapies: A preliminary biodistribution study of PRINTTM nanoparticles. J Control Release. 2007;121:10-18.

171. Gratton SE, Ropp PA, Pohlhaus PD, et al. The effect of particle design on cellular internalization pathways. Proc Natl Acad Sci U SA. 2008;105:11613-11618.

172. Gratton SE, Napier ME, Ropp PA, Tian S, DeSimone JM. Microfabricated particles for engineered drug therapies: elucidation into the mechanisms of cellular internalization of PRINT particles. Pharm Res. 2008;25:2845-2852.

173. Li X, Blondino FE, Hindle M, Soine WH, Byron PR. Stability and characterization of perphenazine aerosols generated using the capillary aerosol generator. Int J Pharm. 2005;303:113-124.

174. Avram MJ, Henthorn TK, Spyker DA, et al. Recirculatory pharmacokinetic model of the uptake, distribution, and bioavailability of prochlorperazine administered as a thermally generated aerosol in a single breath to dogs. Drug Metab Dispos. 2007;35:262-267.

175. Rabinowitz JD, Wensley M, Lloyd P, et al. Fast onset medications through thermally generated aerosols. J Pharmacol Exp Ther. 2004;309:769-775.

176. Hong JN, Hindle M, Byron PR. Control of particle size by coagulation of novel condensation aerosols in reservoir chambers. JAerosol Med. 2002;15:359-368.

177. Gupta R, Hindle M, Byron PR, Cox KA, McRae DD. Investigation of a novel condensation aerosol generator: solute and solvent effects. Aerosol Sci Technol. 2003;37:672-681.

178. Rabinowitz JD, Lloyd PM, Munzar P, et al. Ultra-fast absorption of amorphous pure drug aerosols via deep lung inhalation. J Pharm Sci. 2006;95:2438-2451.

179. Myers DJ, Timmons RD, Lu AT, et al. The effect of film thickness on thermal aerosol generation. Pharm Res. 2007;24:336-342.

180. Hickey AJ, Mansour HM, Telko MJ, et al. Physical characterization of component particles included in dry powder inhalers. I. Strategy review and static characteristics. J Pharm Sci. 2007;96:1282-1301.

181. Williams RO, 3rd, Brown J, Liu J. Influence of micronization method on the performance of a suspension triamcinolone acetonide pressurized metered-dose inhaler formulation. Pharm Dev Technol. 1999;4:167-179.

182. Barry PW, O'Callaghan C. An in vitro analysis of the output of budesonide from different nebulizers. J Allergy Clin Immunol. 1999;104:1168-1173.

183. Schauer JJ, Christensen CG, Kittelson DB, Johnson JP, Watts WF. Impact of ambient temperatures and driving conditions on the chemical composition of particulate matter emissions from nonsmoking gasoline-powered motor vehicles. Aerosol Sci Technol. 2008;42:210-223.

184. Miguel A, Eiguren-Fernandez A, Sioutas C, Fine P, Geller M, Mayo P. Observations of twelve USEPA priority polycyclic aromatic hydrocarbons in the aitken size range (10-32 nm Dp). Aerosol Sci Technol. 2005;39:415-418.

185. Park K, Cao F, Kittelson DB, McMurry PH. Relationship between particle mass and mobility for diesel exhaust particles. Environ Sci Technol. 2003;37:577-583.
186. Sardar SB, Fine PM, Mayo PR, Sioutas C. Size-fractionated measurements of ambient ultrafine particle chemical composition in Los Angeles using the NanoMOUDI. Environ Sci Technol. 2005;39:932-944

187. Lin CC, Chen SJ, Huang KL. Characteristics of metals in nano/ultrafine/fine/coarse particles collected beside a heavily trafficked road. Environ Sci Technol. 2005;39:8113-8122.

188. Geller MD, Kim S, Misra C, Sioutas C, Olson BA, Marple VA. A methodology for measuring size-dependent chemical composition of ultrafine particles. Aerosol Sci Technol. 2002;36:748-762.

189. Venkatachari P, Hopke PK, Brune WH, et al. Characterization of wintertime reactive oxygen species concentrations in Flushing, New York. Aerosol Sci Technol. 2007;41:97-111.

190. Fujitani Y, Hasegawa S, Fushimi A, et al. Collection characteristics of low-pressure impactors with various impaction substrate materials. Atmos Environ. 2006;40:3221-3229.

191. Bates S, Zografi G, Engers D, Morris K, Crowley K, Newman A. Analysis of amorphous and nanocrystalline solids from their X-ray diffraction patterns. Pharm Res. 2006;23:2333-2349.

192. Larhrib H, Zeng XM, Martin GP, Marriott C, Pritchard J. The use of different grades of lactose as a carrier for aerosolised salbutamol sulphate. Int J Pharm. 1999;191:1-14.

193. Traini D, Young PM, Thielmann F, Acharya M. The influence of lactose pseudopolymorphic form on salbutamol sulfate-lactose interactions in DPI formulations. Drug Dev Ind Pharm. 2008;34:992-1001.

194. Newman AW, Byrn SR. Solid-state analysis of the active pharmaceutical ingredient in drug products. Drug Discov Today. 2003;8:898-905.

195. Saleki-Gerhardt A, Ahlneck C, Zografi G. Assessment of disorder in crystalline solids. Int J Pharm. 1994;101:237-247.

196. Bunker M, Davies M, Roberts C. Towards screening of inhalation formulations: measuring interactions with atomic force microscopy. Expert Opin Drug Deliv. 2005;2:613-624.

197. Sethuraman VV, Hickey AJ. Powder properties and their influence on dry powder inhaler delivery of an antitubercular drug. AAPS Pharm Sci Tech. 2002;3:E28.

198. Mansour HM, Zografi G. The relationship between water vapor absorption and desorption by phospholipids and bilayer phase transitions. J Pharm Sci. 2007;96:377-396.

199. Agu RU, Ugwoke MI, Armand M, Kinget R, Verbeke N. The lung as a route for systemic delivery of therapeutic proteins and peptides. Respir Res. 2001;2:198-209.

200. Groneberg DA, Witt C, Wagner U, Chung KF, Fischer A. Fundamentals of pulmonary drug delivery. Respir Med. 2003;97:382-387.

201. Mathias NR, Yamashita F, Lee VHL. Respiratory epithelial cell culture models for evaluation of ion and drug transport. Adv Drug Deliv Rev. 1996;22:215-249.

202. Forbes B, Ehrhardt C. Human respiratory epithelial cell culture for drug delivery applications. Eur J Pharm Biopharm. 2005;60:193-205.

203. Sakagami M. In vivo, in vitro and ex vivo models to assess pulmonary absorption and disposition of inhaled therapeutics for systemic delivery. Adv Drug Deliv Rev. 2006;58:1030-1060.

204. Mobley C, Hochhaus G. Methods used to assess pulmonary deposition and absorption of drugs. Drug Discov Today. 2001;6:367-375.

205. Steimer A, Haltner E, Lehr CM. Cell culture models of the respiratory tract relevant to pulmonary drug delivery. $J$ Aerosol Med. 2005;18:137-182.

206. Borchard G, Cassará ML, Roemelé PEH, Florea BI, Junginger HE. Transport and local metabolism of budesonide and fluticasone propionate in a human bronchial epithelial cell line (Calu-3). $J$ Pharm Sci. 2002;91:1561-1567.

207. Ehrhardt C, Fiegel J, Fuchs S, et al. Drug absorption by the respiratory mucosa: cell culture models and particulate drug carriers. J Aerosol Med. 2002;15:131-139.

208. Foster KA, Avery ML, Yazdanian M, Audus KL. Characterization of the Calu-3 cell line as a tool to screen pulmonary drug delivery. Int $J$ Pharm. 2000;208:1-11. 
209. Foster KA, Oster CG, Mayer MM, Avery ML, Audus KL. Characterization of the A549 cell line as a type ii pulmonary epithelial cell model for drug metabolism. Exp Cell Res. 1998;243:359-366.

210. Manford F, Tronde A, Jeppsson AB, Patel N, Johansson F, Forbes B. Drug permeability in 16HBE140-airway cell layers correlates with absorption from the isolated perfused rat lung. Eur J Pharm Sci. 2005;26:414-420.

211. Lin H, Li H, Cho HJ, et al. Air-liquid interface (ALI) culture of human bronchial epithelial cell monolayers as an in vitro model for airway drug transport studies. J Pharm Sci. 2007;96:341-350.

212. Vaughn JM, McConville JT, Burgess D, et al. Single dose and multiple dose studies of itraconazole nanoparticles. Eur J Pharm Biopharm. 2006;63:95-102.

213. Yang W, Tam J, Miller DA, et al. High bioavailability from nebulized itraconazole nanoparticle dispersions with biocompatible stabilizers. Int J Pharm. 2008;361:177-188.

214. McConville JT, Overhoff KA, Sinswat P, et al. Targeted high lung concentrations of itraconazole using nebulized dispersions in a murine model. Pharm Res. 2006;23:901-911.

215. Mizuno T, Mohri K, Nasu S, Danjo K, Okamoto H. Dual imaging of pulmonary delivery and gene expression of dry powder inhalant by fluorescence and bioluminescence. J Control Release. 2009;134:149-154.

216. Oberdorster G, Sharp Z, Atudorei V, et al. Extrapulmonary translocation of ultrafine carbon particles following whole-body inhalation exposure of rats. J Toxicol Environ Health A. 2002;65:1531-1543.

217. Heckel K, Kiefmann R, Dorger M, Stoeckelhuber M, Goetz AE. Colloidal gold particles as a new in vivo marker of early acute lung injury. Am J Physiol Lung Cell Mol Physiol. 2004;287:L867-L878.

218. Kato T, Yashiro T, Murata Y, et al. Evidence that exogenous substances can be phagocytized by alveolar epithelial cells and transported into blood capillaries. Cell Tissue Res. 2003;311:47-51.
219. Oberdorster G, Sharp Z, Atudorei V, et al. Translocation of inhaled ultrafine particles to the brain. Inhal Toxicol. 2004;16:437-445.

220. Oberdorster G. Toxicology of ultrafine particles: in vivo studies. Philos Trans R Soc Lond A. 2000;358:2719-2740.

221. Ballou B, Lagerholm BC, Ernst LA, Bruchez MP, Waggoner AS. Noninvasive imaging of quantum dots in mice. Bioconjug Chem. 2004; 15:79-86.

222. Oberdorster G, Oberdorster E, Oberdorster J. Nanotoxicology: an emerging discipline evolving from studies of ultrafine particles. Environ Health Perspect. 2005;113:823-839.

223. Kreyling WG, Semmler M, Erbe F, et al. Translocation of ultrafine insoluble iridium particles from lung epithelium to extrapulmonary organs is size dependent but very low. J Toxicol Environ Health A. 2002; 65:1513-1530.

224. Oberdorster G, Ferin J, Morrow PE. Volumetric loading of alveolar macrophages (AM): a possible basis for diminished AM-mediated particle clearance. Exp Lung Res. 1992;18:87-104.

225. Oberdorster G, Finkelstein JN, Johnston C, et al. Acute pulmonary effects of ultrafine particles in rats and mice. Res Rep Health Eff Inst. 2000;5-74; disc 75-86.

226. Ferin J, Oberdorster G, Soderholm SC, Gelein R. Pulmonary tissue access of ultrafine particles. J Aerosol Med. 1991;4:57-68.

227. Hickey AJ, Mansour HM. Formulation challenges of powders for the delivery of small molecular weight molecules as aerosols. In: Rathbone MJ, Hadgraft J, Roberts MS, Lane ME, editors. Modifiedrelease Drug Delivery Technology. New York, NY: Informa Healthcare; 2008. p. 573-601.
International Journal of Nanomedicine

\section{Publish your work in this journal}

The International Journal of Nanomedicine is an international, peerreviewed journal focusing on the application of nanotechnology in diagnostics, therapeutics, and drug delivery systems throughout the biomedical field. This journal is indexed on PubMed Central,

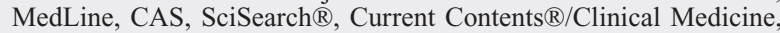

\section{Dovepress}

Journal Citation Reports/Science Edition, EMBase, Scopus and the Elsevier Bibliographic databases. The manuscript management system is completely online and includes a very quick and fair peer-review system, which is all easy to use. Visit http://www.dovepress.com/ testimonials.php to read real quotes from published authors. 